\title{
Beden Eğitimi ve Spor Dersinde Karşılaşılan Sorunların İncelenmesi (Yurt Ị̇i ve Yurt Dışı Değerlendirmesi)
}

\author{
Ceren Nur TEMIZ*1 iD, Ahmet Haktan SIVRIKAYA ${ }^{2}$ \\ ${ }^{1}$ Balıkesir Üniversitesi, Sağlık Bilimleri Enstitüsü, Balıkesir. \\ ${ }^{2}$ Balıkesir Üniversitesi, Spor Bilimleri Fakültesi, Balıkesir.
}

\section{Derleme}

Gönderi Tarihi: 05.03.2021
Kabul Tarihi: 02.05.2021
DOI: 10.47778/ejsse.891512

Online Yayın: 30.06.2021

\section{$\ddot{O} \mathbf{z}$}

$\mathrm{Bu}$ çalışma ile yurtiçi ve yurtdışındaki Beden eğitimi ve spor öğretmenlerinin dersleri sırasında karşılaştıkları sorunlar incelenerek mevcut durum ortaya konmuştur. Çalışma ile öğretmen yetiştiren kurumların, yöneticilerin, yasa ve program yapıcıların dikkatinin çekilmesi amaçlanmıştır. Tüm çalışmalar gösteriyor ki öğretmenler daha çok okul yönetimi, yasa-yönetmelik, müfredat, diğer branş öğretmenleri, öğrenci, veli, tesis, malzeme, zaman, ders işleme, lisans eğitiminden kaynaklı sorunlar yaşamaktadır. Sorunların ana faktörlerinden en önemlisi şüphesiz ki lisans eğitimidir. Benzeri şekilde hizmet içi eğitimlerin yetersiz olması bir diğer göze çarpan faktördür. Mesleğe yeni başlayan öğretmenlerin gerçeklik şoku yaşadığı, yetersiz rehberlik hizmetleri; iş yükünün fazla oluşu, sürekli değişen eğitim sistemi, dersin statüsünün düşük olması gibi nedenlerle öğretmenlerin yoğun stres altında kaldığ 1 ve mesleki tükenmişlik seviyelerinin arttığı, iş ve yaşam doyumlarının düștüğü belirlenmiștir. Eğitim sistemlerinin akademik başarı odaklı olmas1, beden eğitimi dersinin önündeki engellerin dersin işlenişini etkilemesi nedeniyle dersin statüsünün düşük olduğu belirlenmiştir. Sorunların çözümünün kısa vadede gerçekleşmeyeceği açıkça ortadadır. Bu nedenle lisans eğitiminden itibaren yeniden yapılanmaya gidilerek aşamalı olarak güncelleştirmeye gidilmesi gerekmektedir.

Anahtar kelimeler: Beden eğitimi, Beden eğitimi öğretmeni, Mesleki sorunlar, Çözüm önerileri.

\section{Assessing the Problems Encountered in Physical Education and Sport Classes (A Domestic and International Evaluation)}

\begin{abstract}
With this study the current situation was depicted by assessing the problems encountered by the teachers of the physical education and sport during the course both in our country and foreign countries. With the study it was aimed to draw attention of the institutions that educate teachers, administrators and policy and program makers. All the studies indicate that teachers mostly encountered problems that arose from school administrations, laws-regulations, curriculums, teachers of other branches, students, parents, facilities, equipments and materials, teaching and undergraduate education. The most important factor is doubtlessly undergraduate education. Similarly, another remarkable factor is poor in-service trainings. This poor in-service training was due to the following: teachers encountering a reality shock, insufficient guidance, excessive workload, unstable education system, and teaching of courses with low status. The teachers therefore underwent intense stress and suffered from professional burnout and low work-life balance. It has been determined that the course has low value due to a educational focus on academic success, and that the obstacles associated with physical education affect the teaching of the course. It is obvious that problems will not be solved in the short term. Therefore, the teaching of physical education should be restructured from undergraduate education and should gradually be updated.
\end{abstract}

Keywords: Physical education, Physical education teacher, Professional problems, Solution recommendations.

*Sorumlu Yazar: Ceren Nur TEMIZ, E posta: cerennurtemiz@hotmail.com 


\section{GíRIŞ}

Eğitim, bireyin kendi deneyimleri 1şı̆̆ında, önceden belirlenen hedeflere doğru davranış değişikliği meydana getirme sürecidir. Doğumdan ölüme kadar devamlı bir süreç olan eğitim, kişinin yaşadığı toplum içinde değeri olan yetenek tutum ve diğer davranış biçimlerini geliştirdiği süreçlerin tümüdür (Mirzeoğlu, 2013). Eğitim, çevrenin etkisiyle gerçekleştiği gibi istendik ve planlı olarak da yapılabilmektedir. Planlı ve kontrollü bir çevrede, istendik yönde davranış değişikliği meydana getirilmesi eğitim kurumları bünyesinde gerçekleşmektedir. Çağdaş anlayışa uygun olarak eğitimdeki amacın gerçekleşmesi bireyin, zihinsel eğitiminin yanı sıra fiziksel eğitimi ile mümkün olmaktadır (Kangalgil, Hünük ve Demirhan, 2006). Beden eğitimi ve spor sadece fiziksel gelişime olan etkisi ile değerlendirilemeyeceği gibi eğitim bütünlüğü içerisinde bireye kattığı değerlerin önemi göz ardı edilmemelidir.

"Beden eğitimi" ve "Spor" sıklıkla birbirine karıştırılan; birbiri yerine kullanılan iki kavram olarak karşımıza çıkmaktadır. Beden Eğitimi, bireylerin döngüsel hareketsizliklerini kırmak, harekete geçirmek, sahip oldukları hareket kapasitelerini en yüksek seviyede kullanmalarını sağlayan, zihnen ve bedenen iyi, güçlü ve dinamik olma halin iken; Spor, istendik olarak gerçekleştirilen, içinde kuralları barındıran, yarışma, rekabet, kazanma, kaybetme, duygularını içeren performansa dayalı boş zaman aktiviteleridir. İki farklı kavramında girdileri ve çıktıları farklı olduğu gibi eğitimsel bir karmaşaya da neden olmaktadır (Konukman vd., 2010). Beden eğitimi ve spor bireylerin sağlıklı olmalarını sağladığı gibi, yaşamını spor bilinci ile sağlıklı bir şekilde sürdürebilmesine, ahlaklı, kurallara uyan, diğer bireylere değer veren, toplumla uyumlu bireyler yetişmesini sağlar. Bununla beraber yetenekli öğrencilerin uygun spor branşlarına yönlendirilmesini sağlayarak ülke sporumuzu ve uluslararası alanda ülkemizi temsil eden sporcuların yetiştirilmesini destekler. Bu noktada beden eğitimi ve spor derslerinin eğitim faaliyetleri içerisinde önemli bir misyon ve öneme sahip olduğu ortaya çıkmaktadır (Hekim, 2016).

Beden eğitimi ve spor dersleri doğası gereği diğer derslerin farklı olarak incelenmelidir. Beden eğitimi derslerini, dersin yapıldığı ortam, derslerde kullanılan araç gereç, öğretmen ve öğrencilerin kıyafetleri gibi özellikleri ilk bakışta diğer derslerden ayıran özellikler olarak görülebilir (Ünlü ve Aydos, 2010). Beden eğitimi ve spor dersinin sınıfları; spor salonları ve okul bahçeleridir. Normal bir sınıftan daha geniş bir alanda işlenen derslerde öğrencilerin, hareket halinde olması beklenir. $\mathrm{Bu}$ nedenle öğretmenler daimî bir gözlem, güvenlik endişesi içindedir. Normal bir sinıf ortamında bu gibi endişelere çok fazla yer verilmez. Beden eğitimi ve spor dersleri, çalışma ve ders işleme koşullarının zorluğu, veliler, öğrenciler ve yöneticilerle olan ilişkiler, öğrencilerin tutum ve davranışları, altyapı ve malzeme teminleri, öğretmenlerin meslekleri dışında birden fazla ek rollere sahip olmaları, (kulüp başkanlıkları, disiplin sağlama, lider, antrenör, resmi bayramlar da ki görevler, ilk yardım) toplum tarafından dersin değersiz olması gibi nedenler dersin işlenmesini etkileyebileceği gibi hem dersi hem de öğretmeni etkiler. Bu nedenle öğretmenlerin problemlerinin belirlenmesi, beden eğitimi ve spor dersindeki sorunların çözümü sonucu istenilen kazanımların elde edilmesinde etkili olacaktır. Eğitim sistemlerinin en önemli ögesi olan öğretmenlerin ve derste 
karşılaşılan sorunlarının ortaya konarak çözüme ulaştırılması eğitim sistemlerinin sağlıklı bir şekilde çalışmasını sağlayacaktır. Bu nedenle atılan her adım değerlidir. Ortaya konan bulguların değerlendirilmesi, karşılaştırmaların yapılmasının, geçmişten günümüze var olan sorunların ortaya konularak çözüme ulaştırılabilmesi, iyileştirilmesi, tamamlanması gereken yönlerin ortaya konması ile çağdaş eğitim seviyesini yakalayabilmek açısından son derece önemli görülmektedir. $\mathrm{Bu}$ araştırma ile, ülkemizde ve farklı ülkelerdeki beden eğitimi ve spor derslerinde karşılaşılan sorunlar incelenerek farkındalık oluşturmak ve sorunların çözümüne katkı sağlanması amaçlanmıştır.

\section{Beden Eğitimi ve Spor Dersinde Karşılaşılan Temel Sorunlar}

\section{Öğretmen sorunları}

Alan yazın incelendiğinde beden eğitimi öğretmenlerinin karşılaştıkları problemler aşağıdaki şekil ile özetlenmiştir (Şekil 1):

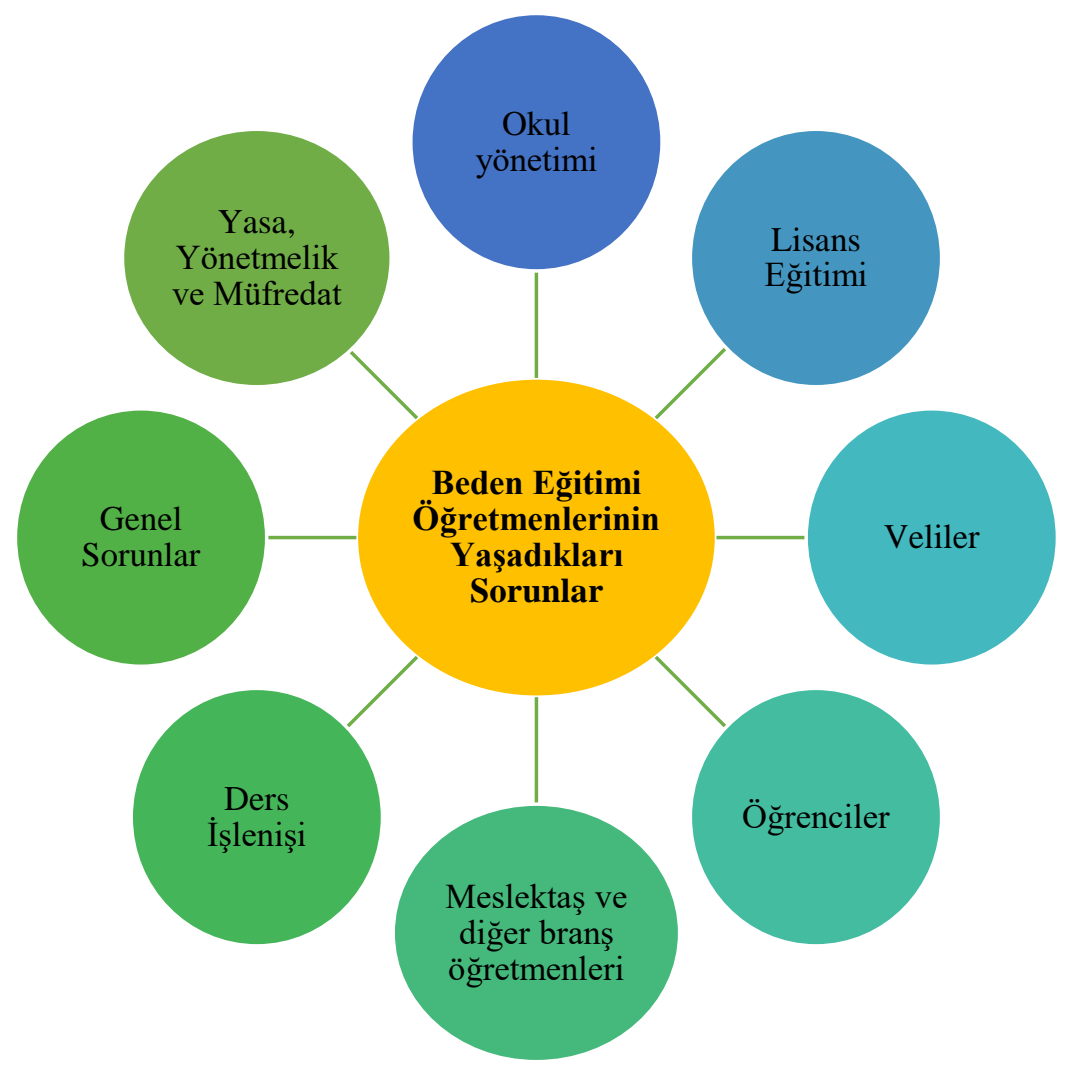

Şekil 1. Beden Eğitimi ve Spor Öğretmenlerinin karşılaştıkları ana sorunlar

Beden eğitimi ve spor öğretmenlerinin yaşadıkları problemler belli temalar altında toplanabilir. Bunlar: okul yönetimi, yasa-yönetmelik, müfredat, öğrenciler, veliler, lisans eğitimi, genel sorunlar olarak sınıflandırılabilir. Özellikle öğretmenlerin malzeme ve tesis eksikliği, sınıfların kalabalık olması, ders saatinin; yöntemleri, teknikleri, modelleri ve müfredatı uygulayabilmek için 
yeterli olmadığı, lisans ve MEB programları arasında uyuşmazlıkların sorunlar yarattığı eksikliklerin müfredat programlarını uygulayabilmelerini engellediklerine (Doğar, 2019; Gülüm ve Bilir, 2011; Güllü, Güllü ve Güllü, 2009; K1lı̧aslan ve Baş, 2020; Rink, 2013; Yıldız ve Kangalgil, 2014) dair çalışmalar bulunmaktadır.

\section{Aileler ile ilgili sorunlar}

Aileler, çocuklarının spora katılımlarında ve spora başlamalarında olumlu ya da olumsuz etkiye sahiptirler. Bu önemli faktör göz önünde bulundurulduğunda beden eğitimi dersinin aile yönlendirmesi ve bireyin gelişimi açısından ne kadar önemli olduğu açıkça görülmektedir (BaxterJones, Maffulli ve TOYA Study Group, 2003; Öncü ve Güven, 2011; Harwood ve Knight, 2016). Beden eğitimi dersinin akademik olarak etkisinin düşük olması, dersi geçmenin kolay olması ve beklentinin bu yönde olması, derse karşı ailelerin bilinçsiz olması, akademik kaygı içinde olmayan öğrenci ve velilerin dersi değersiz görmesi ve derse karşı olumsuz tutum içinde olmasını sağlamaktadır (Güven ve Önce, 2006; Oğul, 2010; Öncü ve Güven, 2011; Sezen, 2019; SanzArazuri, Valdemoros, Ponce De Leon, Baena Exttremara,2018; Yılmaz, Esentürk ve İlhan, 2018).

Sanz-Arazuri vd., (2018) yaptıkları çalışmada beden eğitimi öğretmenlerinin \%62'si, velilerin dersi boşa geçen zaman olarak gördüklerini söylediklerini belirtmiştir. Yılmaz vd., (2018) çalışmasında katılımcılardan biri olan beden eğitimi ve spor öğretmeni, "Veliler yeterince beden eğitimi dersine önem vermiyor. Bazı branşlara yönlendirdiğim öğrencilerin velileri derslerini engeller diye çocuklarını spora yönlendirmiyor. Bu durum benim istek ve arzumu azaltıyor" ya da "Anne-babalar çocuklarının sınav odaklı faaliyet göstermesini istiyorlar. Velilerimizle çoğu zaman dersin yararları ve gerekliliği konusunda iletişim çatışmalarımız oluyor" şeklinde fikirlerini dile getirmişlerdir. Bu sonuçlara bakarak söyleyebiliriz ki öğrencilerin bütünsel ve hayat boyu gelişimlerinden ziyade akademik başarı daha önemli bir yer tutmaktadır.

\section{Okul yönetimi ile ilgili sorunlar}

Yapılan çalışmalar ağırlıklı olarak okul yönetimlerinin beden eğitimi dersini desteklemediği ve sorun yaşandığı noktasında birleşmektedir. Doğar'ın (2019) yaptığı çalışmada okul müdürlerinin ve okul aile birliklerinin \%61,3'ü beden eğitimi dersini kısmen desteklediği belirlenmiştir. Okul müdürlerinin \%89,3'ü öğrencilerin boş zamanlarında sosyal aktivite ya da oyun oynamalarından ziyade öncelikle ders çalışmaları gerektiğini belirtmişlerdir. Jenkinson ve Benson'nun (2010) yaptıkları çalışmada araştırmaya katılan beden eğitimi öğretmenlerinin, $\% 45$ 'i beden eğitimi dersini "önemli” ya da "çok önemli” olarak nitelendirirken \%3'ünün okullarında beden eğitimi dersinin öncelikli ders olarak görüldügünü belirtmişlerdir. Alagül ve Gürsel'in (2018) yaptığı çalışmada, öğretmenlerden bir tanesinin "Bu hafta ders yaparken okul müdiresi geldi ve hocam salonun her yerine öğrenci dağılmış biraz daha toparlansa öğrenciler ve sırayla oynasalar çok dağınık dedi. Bir anda ne diyeceğimi bilemedim. Ama şu anda hepsi aktif diyebildim sadece. Bilemiyorum ne yapsam..." şeklindeki yorumu dikkat çekmektedir. 


\section{Meslektaşlar ve diğer branş öğretmenler ile ilgili sorunlar}

Beden eğitimi öğretmenleri hem meslektaşları hem de diğer branş öğretmenleri ile de sorun yaşamaktadırlar. Yaşanan sorunlara bakıldığında yeterli derece de destek görmedikleri, çoğunlukla zümre toplantılarının nitelikli olmadığı, evrak işlerinin bir iki kişiye üzerinde olması ve iş birliğine varmada problemler yaşadıkları belirlenmiştir. Beden eğitimi öğretmenlerin çakışan ders saatlerinde malzeme ve yer konusunda birbirleriyle problemler yaşamalarının yanı sıra branş öğretmenleri tarafından dersin yeterliliğinin anlaşılamaması, derse karşı ilgisiz olmaları ve mesleği küçümsemeleri gelmektedir (Gökyer, 2011; Sagın, Güllü ve Uğraş, 2020; Villalba, GonzalesRivera ve Diaz-Pulido, 2017; Y1lmaz vd., 2018).

\section{Ölçme ve değerlendirme ile ilgili sorunlar}

Beden eğitimi ve spor da ölçme değerlendirme, eğitimciler arasında "Gri Alan" olarak adlandırılabilir. Öğretmenler tarafından tam olarak nasıl yapılması gerektiğinin bilinememesi, belli bir standarda konulamaması, zaman yetersizliği, kalabalık sınıflar, ayrı zaman gerektirmesi nedeniyle istenilen şekilde gerçekleşmemektedir. Öğretmenler kendilerini belki de en çok bu alanda yetersiz olarak görmektedir. Beden eğitimi dersi akademik başarıya tam olarak etki etmediği gibi ölçme değerlendirmenin doğru şekilde yapılamaması öğretmenlerin problem yaşamamak için yüksek not verme eğiliminde olmalarını sağlamaktadır. $\mathrm{Bu}$ nedenle aileler, öğrenciler ve veliler yüksek not beklentisi içindedir (Asma, Çamlıyer, Soytürk, Balcı, Çamlıyer, 2018; Özkoparan ve İnan, 2018; Uğraş ve Sağın, 2019; Zhu, 2015).

Aka, Arı, Can ve Kale'nin (2011) yaptıkları çalışmalarında öğretmenlerin \%80'i ile \%90'1 öğrencilere hak ettikleri puandan daha fazlasını verdiklerini belirtirken, diğer yandan öğrenci ve veli görüşlerine göre öğrencilerin \%100'nün dersten “yüksek not” ile geçtiği belirtilmiştir (Özcan ve Mirzeoğlu, 2014). Öğretmenlerin \% 45 'i programın değerlendirme kısmında sorun yaşadıklarını \%40'1 ise yeterli olanaklarının ve zamanlarının olmadığını ileri sürmüşlerdir. Yılmaz ve Gündüz'ün (2008) yaptıkları çalışmada beden eğitimi öğretmenlerinin ölçme değerlendirmeyi önemsedikleri ancak bulundukları şartlardan dolayı (müfredat yoğunluğu, kalabalık sınıflar, yetersiz zaman, öğrenci tutumları) gerektiği gibi yapamadıklarını ifade etmişlerdir. Yıldız ve Yıldız'ın (2019) yaptığı çalışmada alternatif ölçme değerlendirme yöntemlerini kullanma düzeylerinin tesis, araç, gerece sahip olmak ile değişmediğini saptamışlardır. Yine aynı çalışmada öğretmenlerin ölçme değerlendirme yöntemlerine karşı yeterli düzeyde bilgiye sahip olmadığ 1 belirtilmiş̧ir. Kılıçaslan ve Baş (2020) bu durumu şöyle açıklamaktadır; yapılandırmacı yaklaşımın benimsendiği ölçme-değerlendirme de öğretmenler bu yaklaşımı, öğrencilerin kendi kendilerini gözlemlemesine imkân sağlayacağı ve dersin verimliliğini artıracağı görüşündedir. Fakat zaman faktörü ve gerekliliğine inanılmamanın, bu ölçme ve değerlendirme yaklaşımın uygulanmasının önündeki engellerden biri olduğu da vurgulanmaktadır. Uğraş, Güllü, Eroğlu ve Özen (2017) ise bu durumu öğretmenlerin fazladan iş yükü ve gereksiz olarak gördüklerini, idare ve müfettişler ile sorun yaşamamak için yaptıklarını belirtmiştir. Bunun nedeninin ise lisans dönemin de ki eğitimsel sorunlar ve yeterli bilgiye sahip olmadıklarına bağlamıştır. Beden eğitimi öğretmenleri ölçme değerlendirme aşamasında problemler yaşamalarına bağlı olarak sürekli derste 
verilen notlar ile ilgili dolaylı olarak idarecilerin ve velilerin baskılarına maruz kalmaları, objektif değerlendirme yapamamaları, problem yaşamamak için her öğrenciye yüksek not vermeleri, gerekli görmemeleri, yeterli bilgiye sahip olmamaları ile diğer branş öğretmenleri tarafından temel bilimlere verilen değerin verilmemesi beden eğitimi dersinin statüsünü ve önemini düşürmektedir (Avşar, 2009; Karaküçük, 1999; Marshall ve Hardman, 2000; Richardson, 2011; Uğraş vd., 2017).

\section{Lisans eğitimi ile ilgili sorunlar}

Öğretmenlerin meslek hayatlarında yaşadıkları sorunların belki de en temel nedeni aldıkları lisans eğitimleridir. Yeni mezun olan öğretmenlerden beklenen yeterliliklere bakıldığında; alan bilgisi ve mesleki yeterliliğe sahip, sınıf yönetimi, rehberlik, ölçme değerlendirme, planlama, araç-gereç kullanımı, genel ve özel öğretim yöntem ve tekniklerini kullanabilen; alanlarında yeterli ve öğretmenlik mesleğine uygun özelliklere sahip bireyler olarak mezun olmaları beklenmektedir. Ancak gerçeğe döndüğümüzde öğretmen adaylarının lisans eğitimi sırasında birçok tesis ve malzemeye sahip olarak eğitim görmeleri ile saha da alt yapı eksikliği ile nasıl ders işleyeceklerini bilememelerine neden olmakta; genel eğitim ve beden eğitime özgü pedagojik eğitimlerin yetersiz olması, lisans eğitimi ders programı ile MEB'e bağlı okulların müfredat programlarının farklı olması uyuşmazlık yaratmaktadır. Yıldız ve Kangalgil'in (2014) beden eğitimi öğretmenleri ile yaptıkları çalışmada öğretmenlerin \%31'i mezun oldukları bölümde yeterli düzeyde özel öğretim yöntemleri dersi aldıklarını belirtmiş̧ir. Sağın ve Karabulut'un (2020) yaptıkları çalışmada öğretmenlerin alan bilgisi, ders öncesi hazırlık, planlama ve uygulama, sınıf yönetimi, ölçme ve değerlendirme gibi öğretmenlik mesleğinin en önemli mihenk taşlarında almış oldukları eğitimi yeterli görmemektedirler. Özellikle sınıf yönetimi, gerekli dosyaları hazırlama, ders planı ve içerik hazırlama, not girişi, e-okul, karne hazırlama gibi önemli evrakları hazırlamakta sorunlar yaşadıklarını belirttikleri çalışmalarda bulunmaktadır (Richardson, 2011; Uğraş vd., 2017). Lisans eğitiminde meydana gelen uyuşmazlık öğretmenlerin mesleğe hazır olarak mezun olmadıklarını aynı zamanda verilen eğitimin yeterli olmadığını gözler önüne sermektedir. Kızılkaya Namlı ve Temel'in (2019) yaptıkları araştırmada; beden eğitimi öğretmenleri, programının ihtiyacı karşılayamadığı ve ders içeriğinin zayıf olduğu, MEB ile öğretim programı arasında ki uyuşmazlık, uygulamalı derslerin azlığı ve teorik ders yükünün fazla oluşu, zaman ve öğretim elemanı yetersizliği, stajın yetersizliği, meslek bilgisi derslerinin beden eğitimi alanına aktarmakta zorluk yaşamalarının öğretmen adaylarının en önemli dersleri anlayamamalarına neden olduğu; özellikle özel öğretim yöntemleri derslerinin ders saatinin azlı̆̆ı nedeniyle spora özgü yöntemleri öğretememelerine neden olduğunu belirtmişlerdir. Aynı zamanda öğretim elemanlarının öğretim programının işleyişi ve yaşanan aksaklıklar nedeniyle öğretmen olarak değil birer antrenör yetiştirmek durumunda kaldıklarını belirttikleri çalışmalar da yer almaktadır (Demirhan vd., 2008; Konukman vd., 2010; Kızılkaya Namlı ve Temel, 2019). 


\section{Ders saati ve malzeme ile ilgili sorunlar}

Motor becerileri öğrenmek belli bir zaman almaktadır. Öğrencilerin çoğunun hafta da 1-2 saat katıldıkları beden eğitimi ve spor dersleriyle, temel becerileri geliştirecek zamanı olmamaktadır (Mirzeoğlu, 2017 s. 15). Öğretmenler, lisans eğitiminin yetersizliğine bağlı olarak; malzeme ve tesis eksikliği ile nasıl ders yapacaklarını bilememeleri, öğrenci merkezli öğretim yöntem ve tekniklerini kullanamamakta, spor etkinlikleri düzenleyememekte, sadece birkaç spor branşında ve tek tip ders işlemek zorunda kalmaktadır. Bu görüşü destekleyen Özcan ve Mirzeoğlu'nun (2014) yaptıkları çalışmalarında öğrencilerin \%100'ü ve velilerin \% 70'i beden eğitimi derslerinin belli başlı spor branşları ile sınırlı kaldığını ifade etmiştir. Öğretmenlerin \%65'i okulun yetersiz olanaklarını dile getirirken \%55'lik kısmı ise öğretim programını tam olarak anlayamadıklarını ve eski bilgileri ile ders işlediklerini dile getirmişlerdir. Yılmaz vd., (2018) beden eğitimi öğretmenlerinin mesleki tükenmişliklerine yol açan nedenleri inceledikleri araştırmalarında katılımcıların \%100'ü dersin verimli olarak işlenmeme nedeninin malzeme ve materyal eksikliği olduğunu belirtmişlerdir. Beden eğitimi öğretiminde, öğretim sürecinin içini dolduran, öğretim hedeflerine ulaşmayı sağlayan ders etkinliklerinin en önemli unsurları öğretim araç-gereçleri ve materyalleridir (Demirci, 2013 s.61). Ancak yapılan çalışmalara baktığımızda öğretmenlerin en çok problem yaşadıkları kısım ise araç-gereçlere ulaşım sorunudur. Eğitim kurumunun beden eğitimi dersi için gerekli olan malzemeye sahip olması hem öğretmenin hem öğrencinin motivasyonu açısından önemlidir (Erhan ve Tamer, 2009).

Öğretmenler, öğretim programlarını tam olarak anlayamadıkları, lisans eğitimi yeterli düzeyde eğitim görmedikleri bu nedenle özel öğretim yöntemlerini kullanamadıklarını, öğretmenlerin bilgisizliği, hizmet içi eğitimlerin yeterli olmayışı, araç, gereç ve ders saatinin yetersiz olduğunu belirtirken, öğrencilerin isteksizlikleri, sınıfların kalabalık olması nedeniyle uygulama da zorluk çektiklerini, belirtmişlerdir (Chatoupis, 2018; Demirhan vd., 2008; Erhan ve Tamer; 2009; Jaakkola ve Watt, 2011; Popeska, Klincarov, Nokovski ve Mitevski, 2017; Şirinkan ve Erçiş, 2009; Ünlü ve Filiz 2019; Veloo ve Md-Ali, 2016; Yıldız ve Kangalgil, 2014; Yıldız, Yıldız ve Çağlayan, 2013). Yıldız vd., (2013) araştırmalarında katılımcıların \%58'i öğretim yöntemlerini yararlı bulduğunu ifade etmiştir. Araştırmada göze çarpan yorumlarda bulunmaktadır: "Üniversite eğitimim sırasında bu yöntemler hakkında bir eğitim almadım, yeterli bilgim yok. Bu nedenle yöntemleri uygulayamadığımdan yararlı olmuyor" ya da "yeni yöntemleri uygulamıyorum. Çünkü kolay anlaşılır yöntemler değil sadece evrak kalabalığı..." yorumları dikkat çekmektedir. $\mathrm{Bu}$ yorumdan yola çıkarak lisans eğitiminin programın beklentilerini karşılayabilme yetisini kazandırmada ne kadar önemli olduğunu bir kez daha göstermektedir. Bu durumların eksikliği dışarıdan bakıldığında veliler, öğrenciler ve yöneticiler tarafından dersin "boşa zaman harcanan" bir ders olarak görülmesine neden olmaktadır. Ancak dersin uygulaması önünde büyük engeller bulunmaktadır. 
Temiz, C.N. ve Sivrikaya, A.H. (2021). Beden eğitimi ve spor dersinde karş̧laşılan sorunların incelenmesi (Yurt içi ve yurt dişı değerlendirmesi). Avrasya Spor Bilimleri ve Ĕ̈itim Dergisi, 3(1), 12-39.

\section{Okul deneyimi ve öğretmenlik uygulaması ile ilgili sorunlar}

Araştırmalara bakıldığında öğretmen adaylarının kendilerini en olumlu yönde etkilen dersler olarak belirttikleri uygulama dersleri, öğretmenlik mesleğinin gerçek yüzünü göstermekte ve öğretmen adaylarını mesleğe hazırlamaktadır. Ancak teorik olarak aldıkları eğitimi saha da uygulayamamaktadırlar (Atasoy, 2008; Bulca, Saçl, Kangalgil, Demirhan, 2012; Çınar, 2011; Demir, 2018; Erhan, 2009; Hoşkilimci, 2011; Kangalgil ve Özgül, 2019; Karabulutlu ve Pulur, 2017; Erbaş ve Ünlü, 2012; Keske, 2007, Kırekin, 2016; Kızılkaya Namlı ve Temel, 2019; Mercan, 2020; Richards, Templin ve Gaudreault, 2013; Taymaz, 2011; Yaşar, 2008; Yüzüak, 2006). Seçer, Çeliköz ve Kayılı (2010) çalışmalarında, okul uygulamalarında yaşanan sorunlar arasında en fazla; uygulama öğretmenlerinin okul deneyimi ders içeriklerini ve sorumluluklarını bilmemeleri; okul ve üniversite arasında iş birliği, iletişim ve koordinasyon sağlanamaması; okullara ulaşım ile ilgili sorunlar, öğretmen adaylarının uygulama alanlarında motive olamamaları ve denetim eksikliğinin yanında öğrenci sayılarının fazla olması ve uygulama okulu azlığından söz etmişlerdir.

\section{Türkiye'de Beden Eğitimi ve Spor Dersindeki Sorunlar}

Sönmez ve Sunay (2004) özel ve devlet okullarında yaptıkları çalışmalarında öğretmenlerin ve okulların sahip olduğu imkanlar nedeniyle aralarında ciddi farklar görmüşlerdir. Devlet okullarında görev yapan öğretmenlerin özellikle belirttiği konu yetersiz malzeme, tesis ve kalabalık sınıflardır. Özel okullarda görevli öğretmenlerde böyle bir sorun görülmezken okul idaresinin ve velilerin tutumlarının daha olumlu olduğu da bir başka sonuçtur. Özel okulların sahip oldukları imkanların daha iyi olmasının hem dersin işlenişi hem de derse karşı olan tutumu doğrudan etkilediği görülmektedir.

Ancak en dikkat çekeni her iki kurumda görevli olan öğretmenler ortak paydada buluşmalarını sağlayan konu, dersin hedefleridir. Her iki kurumdaki öğretmenler dersin hedefini kısmen gerçekleştirebildiklerini ve ders saatinin yetersiz olduğunu vurgulamışlardır.

Taşmektepligil, Yılmaz, İmamoğlu ve Kılcıgil'in (2006) ilköğretim okullarının beden eğitimi derslerinin hedeflerini gerçekleştirme düzeylerini inceledikleri çalışmalarında hem öğretmenlerin hem de öğrencilerin görüşlerine başvurmuşlardır. Öğretmenler, dersin hedeflerine ulaşmakta tesis, araç ve gerecin önemine değinmişlerdir. Öğretmenler müfredat programlarını uymaya çalışmaktadırlar ancak sınıfların kalabalık olması, hava şartlarının müsaade etmemesi, yetersiz malzeme ve tesis dersin işlenişini doğrudan etkilediğini ortaya koymuşlardır. Bir diğer ders engeli ise, okulların spor odalarının bulunuyor olmasına rağmen soyunma odalarının bulunmadı̆̆ıdır. Öğrenciler dolaylı olarak derse geç kalmakta ve uyum sorunu yaşamaktadır. En göze çarpan sonuç, öğretmenlerin \%59,1'nin ders malzemesinin yetersizliğini belirtmesidir. Bu durum öğretmen merkezli uygulamalara itmekte öğrenci merkezli uygulamaları göz ardı edilmesini sağlamaktadır.

Çolakoğlu ve Karaküçük'ün (2006) çalışmalarında, sorunların başında ödenek ve malzeme yetersizliği gelmektedir. Örneğin, okullar arası yapılacak olan etkinliklerde öğretmenler maddi yetersizlik, malzeme sorunu ve tesise erişimde sorun yaşadıkların etkinlikleri düzenlemekte engellerle karşılaşmaktadırlar. Öğretmenler, dersin sadece fiziksel ve bedensel gelişimden ziyade, öğrencileri spor branşlarına yönlendirerek ülke sporuna katkıda bulunduğunu ve sporun toplumda 
yaygınlaşmasında yararlı bir araç olduğunu da ifade etmişlerdir. Ancak buna karşın düzenleyecekleri etkinliklerde hakem bulmakta zorlanıyor ve okul idaresi ile de sorun yaşamaktadırlar. Bu sorunlara ilaveten velilerle çatışmalar ve öğrencilerin ilgisiz davranışlarının varlığına da değinilmiştir.

Demirhan vd., (2008) araştırmasının ders engellerinin başında ders süresinin yeterli gelmemesi, sınıfların kalabalık olması, malzemelerin yetersizliği gelmektedir. Öğrencilerin olumsuz tutumları ise bu engellerini devamını oluşturmaktadır. Ergenliğe bağlı olarak cinsiyet çatışmaları kendini göstererek sınıfa yansımakta, kız öğrencilerin olumsuz tutumları kendini hissettirmektedir. Öğrencilerin kıyafetlerini getirmemeleri, derse katılımın az olması ve saygısız davranışlar için olmaları dersin işlenişini zorlaştırmaktadır. Okul yönetiminin derse olumsuz bakması ise başka bir kritik noktadır. Olumsuz tutuma sahip oldukları gibi dersi önemsiz görmekte ve dersin verimliliğini okul takımının elde ettiği başarılara göre değerlendirmektedirler. Ancak her nasılsa okul dışı yapılan etkinliklere (öğretmen ve öğrenci) katılımı engellemeleri ve istememeleri; ders için gerekli malzeme teminin yapmadıkları da belirlenmiştir. Buna rağmen öğretmenlerinin yetkinliklerini öğretmen olarak değil antrenör olarak değerlendirmektedir. Okul yönetiminin tutumu okul çevresinin derse karşı bakış açısının yansımasıdır. Spor kültüründen gelmeyen akademik odaklı olan veliler derse karşı ilgisiz olmakta ve ders sorumluluğunu karşılamamaktadır. İdarenin tutumu, velilerin çocuklarının almış oldukları düşük not için öğretmeni sorgulayabileceklerine işaret etmektedir. Nitekim öğretmenler bu konuda sorun yaşamaktadır. Bunlara ek olarak, maaşlarının yetersizliği, sürekli değişen yasa ve yönetmeliklerin takibini yapamadıkları, yapılan denetlemelerin yüzeysel olması ve rehberlik etmekten uzak olması de cabasidır.

Gülüm ve Bilir'in (2011) beden eğitimi programlarının uygulanabilme koşullarını inceledikleri çalışmalarında, programların hedeflenen çıktılara ulaşmasında fiziksel şartların ve malzemelerin yetersizliğine dikkat çekmişlerdir. Dersin birincil engel nedeni kalabalık sınıflar olarak belirlenirken öğretmenler hizmet içi eğitimin yetersizliğine dikkat çekmişlerdir. Hizmet içi eğitimlerin yetersizliği, değişen programları takip etmelerini zorlaştırmakta, anlayamadıklarından dolayı programın isteğini gerçekleştiremediklerini belirtmişlerdir. Teoriden uygulamaya geçişte sorunların varlığı programın hedeflerini gerçekleştirilmesini güçleştirmektedir. Okul yöneticilerin ve müfettişlerin beden eğitimi dersiyle ilgili yeterli bilgiye ve donanıma sahip olmamaları dersin ihtiyaçlarının karşılanmasını ve katkı sağladığı gelişim alanlarının da göz ardı edilmesini ve statüsünü de düşürmektedir.

Aydoğan'ın (2011) araştırmasında, cinsiyet değişkeni açısından kadın beden eğitimi öğretmenlerin strese neden olan sorunlara daha fazla maruz kaldığını belirlemiştir. Köy okulunda olan öğretmenler fiziksel şartlara, yarışma merkezlerine ulaşımda ve imkanlarının kısıtlılığına değinmiştir. Ulaşım, tesis ve malzeme eksikliği, merkezden uzak olan okullarının sorunlarının ana kaynağı gibi görülmektedir. Örneğin il merkezine göre ilçedeki okullarda iklime bağlı ders işlenmesinde karşılaşılan sorunlar kendini daha çok göstermektedir. Okulun bulunduğu yere göre, öğretmenlerin algıladıkları sorunlarda farklılık göstermektedir. 
Ulucan, Türkçapar ve Cihan (2012) tarafından yapılan araştırmada akademik başarı odaklı eğitim dikkat çekmektedir. Öğrencilerin sınavlara hazırlanmaları nedeniyle aileleri tarafından ders önemsiz olarak görülmektedir. Bu durum öğrencilerin tutumlarını ve derse olan katılımlarını etkilemektedir. Öğretmenler, okul yönetimiyle sorunlar yaşamakta, meslektaşları tarafından ders yeterli düzeyde önemli gözükmemektedir. Haliyle belirgin derecede dersin statüsünü sarsmaktadır. Bu problemlerin dışında okullardaki malzeme ve fiziki şartların yetersizliği, hayat şartları, iş yükü ve ekonomik sıkıntılardan dolayı stres altında hissederek duygusal olarak iyi hissetmemektedirler.

Kul ve Hergüner'in (2018) çalışmalarında çarpıcı sonuçlar bulunmaktadır. Dersin etkili ve verimli işlenmesinin önünde aşılması gereken engeller bulunmaktadır. Literatürü güçlendiren örnek verilecek olursa, araç-gereç eksikliği, yeterli sayıda öğretmenin bulunamaması, kalabalık sınıflar, ekonomik problemlerdir. Araştırma sonuçlarına göre beden eğitimi öğretmenlerinin, performanslarının en çok etkilendiği sorun ekonomik nedenler olarak belirlenmiştir. $\mathrm{Bu}$ problemler, programın hedeflerine ulaşmayı engellemektedir. Programlar ayrı bir ana kaynak sorun olarak nitelendirilebilir. Mevcut ders saati programın isteklerini yerine getirmeyi engellemekte, ünite dağılımlarının uygun olmaması, programda istenilen araç ve gerece ulaşımın olmaması, ilköğretim kademelerinde uyumsuzluk ve ortaöğretim programında bütünlük olmaması da ayrı bir sorun teşkil etmektedir. Performanslarını önemli derece de etkileyen diğer sorunlar; ders işleyişi, yönetmelik, okul yönetimi, veli-öğretmen ilişkisi, öğrenciler, tesis ve malzeme eksiliği çatısı altında toplanabilir. Veli nedenli verilebilecek en net örnek, öğrencilerin ders dışı sportif etkinliklere katılımlarını engellemeleridir. Bunun nedeninin sporun çocuğun hayatında önemi kavrayamamaları olarak sayılabilir. Sınıfı geçmenin çok kolay olması öğrenciler tarafından derse karş1 tutumları da düşürmektedir. Öğretmenler kendilerini güncellemekte sorun yaşadıklarında yetersi hissetmektedirler. Okul yönetiminin yeterli desteği vermemesi ve branş öğretmenleri tarafından önemli sayılmaması da performanslarını son derece etkilediği saptanmıştır.

Uğraş'ın (2018) araştırmasında, lisans eğitiminin önemine değinmiştir. Öğretmenler, mesleklerinde yaşadıkları sorunları aldıkları eğitimlere dayandırmıştır. Öğretmenler aldıkları derslerin saha ile uyumuna dikkat çekmiştir. Örneğin; öğretim yöntemlerini etkili şekilde almamış olmaları nedeniyle bilgi aktarımında sorun yaşamakta, lisans eğitimi sırasında gördükleri eğitim ile milli eğitim programındaki uyumsuzluğun uygulamada sorun yarattığı, seçmeli olarak gördükleri derslerin milli eğitimde zorunlu olması ve okul takımı çıkartmakta problemler yaşamaları verilebilir. Hizmet içi eğitimin yetersizliği kendini hissettirirken bilgi yetersizliği sonucu ölçme yöntemlerini bilmemeleri dersi etkilemektedir. Lisans eğitiminde; mevzuat, yasa, yönetmelik ve özlük haklarında bilgi almamış olmaları ise mesleklerini etkilemektedir.

Yılmaz ve Cihan'ın (2018) araştırmalarında, okul yöneticilerinin beden eğitimi dersini öğretim açısından yararlı bulmalarına rağmen öğretmenleri daha çok disiplin sağlayıcı olarak görüldüğünü 
belirlemiştir. Ders saatinin yetersizliği, malzeme ve tesis eksikliği ve ortak kullanım alanlarında çakışmaların meydana gelmesi dersin verimli işlenme engellerinin arasındadır. Ders için uygulama alanının olmaması ya da okul bahçesinde birden fazla sınıf ile ders işlenmesi, ders işlenişini ve statüsünü etkilemektedir. Öğretmenler bunun sonunda dersin önemsiz olarak algılandığını düşündüklerini ifade etmiştir. Diğer branş öğretmenleri, veliler ve idare tarafindan yeterli önem gösterilmediği de not düşülmüştür.

Yılmaz vd., (2018) çalışmalarında; öğrenci nedenli sorunların başında, disiplinsiz davranışlar ve yeterli düzeyde çaba göstermedikleri gelmektedir. Altyapı ve malzeme eksikliği fiziksel olarak dersin işlenişini etkilerken derslerin kalabalık olması, ders saatinin azlığı ise ders verimliliğini etkilemektedir. Literatürü destekleyen bir diğer sonuç ise ilgisizliktir. Veliler, idare ve diğer ögretmenler derse karşı yeterli sayg1 ve ilgi düzeyine sahip değildirler. Bu durum beden eğitimi öğretmenlerinin meslek olarak değerinin düşmesine neden olmaktadır. Mesleğe yeni başlayan öğretmenlerde kendini gösteren sorun, lisans eğitimidir. Yeni öğretmenler, öğrencilerle iletişim kurmada ve bilgilerini öğrencilere aktarmada sorunlar yaşadıkları, öğrencilerin dikkatlerini çekmede, uygulama esnasında yaşanacak herhangi bir sağlık sorununda nasıl davranacaklarını tam olarak bilmediklerini ve bu nedenle endişeli olduklarını ortaya koymuştur.

Mirzeoğlu, Yaralı, Çoknaz ve Özmen'in (2019) araştırmasında öğretmenler ders işleme verim engelleri benzeri şekilde ders saatinin yetmemesi, salon ve malzeme eksikliği olarak belirtilmiştir. Beden eğitimi dersi diğer öğretmen ve idare tarafından ders olarak değil de bir disiplin yöntemi olarak görülmektedir. Nitekim bu öğretmene ilave rol yüklemektedir. Bunlar bir tarafa öğretmenler yapacakları etkinliklerde bürokratik engellerle karşılaşmaktadır. Okul yöneticilerinden ve diğer branş öğretmenlerinden yeterli desteğin görülmemesinin yanı sıra kendi meslektaşları da sorun oluşturmaktadır. Beden eğitimi derslerinde öğrencileri boş bırakan meslektaşlarının beden eğitimi dersine yönelik eski tutumun değişmesine engel olduklarını ifade etmişlerdir. Öğrenciler, spor yapmaktan utandıkları ve derse olan ilgisizliklerini de dile getirmişlerdir. Ayrıca lisans eğitiminin önemine değinerek öğretmenlik eğitimi sırasında mesleğe uygun eğitim almadıklarını, lisans eğitimi sırasında öğretmen olmaktan çok antrenör olarak yetişmelerine neden olan program gördüklerini belirterek derslerin antrenör ya da sporcu olarak yetiştirilmesini engelleyecek daha yenilikçi derslerin olması gerektiğinin altını çizmişlerdir.

Ünlü ve Filiz'in (2019) yaptıkları çalışmalarında, öğretmenler, akademik odaklı eğitim sisteminin olmasının öğrencilerin beden eğitimi dersinin "gereksiz ders" olarak algılamalarının kaynağı olduğunu ve sürekli değişen eğitim politikalarının mevcut olan eğitim sistemine zarar verdiğini belirtmişlerdir. Okul yönetiminde yeterli destek görmediklerini, olumsuz tutum içinde olmalarının, yapacakları etkinlikleri de etkilediğini ifade etmişlerdir. Ders işlenişin birincil sorunu olan malzeme ve ekipman eksikliği kendini göstermektedir. Sorun yaşanan bir diğer alan ise öğrenci davranışlarıdır. Yetersiz ekipmana sahip olmanın öğrencilerin dersten sıkılmalarına neden olduğu, derse katılımın azaldığı, aktivitelere katılmama ya da disiplinsiz davranışlara sahip olduklarını 
belirtmiştir. Bunlara ek olarak yeterli ücret almadıklarını düşünmekte, derse karşı gerekli özenin ve saygınlığın verilmediğini, statüsünün düşün bir ders olarak kaldığını bildirmiştir.

Doğar'ın (2019) okul müdürlerinin gözünden, beden eğitimi öğretmenlerinin yaşadıkları sorunları incelediği araştırmasında çarpıcı sonuçlar bulunmaktadır. Araştırmaya katılan okulların sadece \%2,7'sinin kapalı spor alanı olduğunu belirlemişlerdir. İklim koşulları göz önüne alındığında tesis yetersizliği, derslerin kışın, soğuk, yağmurlu ya da aşırı sıcak günlerde işlenememekte ve müfredata uygun gidilememesi ile sonuçlanmaktadır. Okulların maddi açıdan yetersiz kaldığı düşünüldüğünde mahalli idarelerden destek beklenme ancak yeterli düzeyde yardım gelmediği belirtilmiştir. Malzeme, tesis ve saha eksikliğine ek olarak okul aile birliğinin, dersi kısmen destekliyor olması okul takımlarının kurulmasını engellemektedir. Okul müdürlerine göre dersin önündeki en büyük engel saha, malzeme ve tesis yetersizliğidir. Ancak araştırmaya katılan müdürlerin, öğrencilerin boşa kalan zamanlarının $\% 4,1$ ' sporla uğraşması, \%1,3'ününse önce oyun oynanması gerektiğini çelişki ifade etseler de akademik başarı odaklı olduklarını göstermektedir. Okul aile birliğinin ilgisizliği, yetersiz malzemeler, mahalli idarelerin desteğinin olmaması, öğretmenlerimizin temel malzemelere (Futbol, voleybol, hentbol, basketbol topu) sahip olmasına ve belli başlı branşları işlemek zorunda bırakarak kar topu misali sorunlarının oluşmasının zeminin hazırlamaktadır.

Uğraş ve Güllü’nün (2019) çalışmasında meslek öncesi eğitimin önemine vurgulanmaktadır. Sahaya uygun yetişmeyen yeni öğretmenler sorunlarla çarpışmaktadır. Bunun en net örneği lisans eğitiminin milli eğitim ile uygulamada farklılık göstermesidir. Milli eğitim bakanlığının zorunlu tuttuğu konuların lisans eğitiminde almamaları ya da az görmüş olduklarından uygulamada yaşanan sorunlara neden olmaktadır. Staj eğitimi gibi mesleği birincil cepheden gördükleri derslerin önemini vurgularken öğretmenlik uygulaması ya da stajın eksikliğinin derse başladıkları sırasında tedirginliklerini giderememelerine, öğretim yöntemlerini kullanmakta sorun çekmelerini sağlamıştır. Buna bağlı iş ortamına uyum sağlamakta sorun yaşamaktadırlar. Bir öğretmen gibi yetişmektense sporcu ya da antrenör gibi yetiştiklerini, mesleğe başladıklarında öğrendikleri konuları öğrencilere nasıl aktaracakların bilememelerine yol açtı̆̆ına değinmişlerdir. Bu durum teorik ders ve uygulamalı ders dengelerinin ne kadar önemli olduğuna işaret etmektedir.

Uğraş, Güllü ve Yücekaya'nın (2019) beden eğitimi öğretmenleri mesleklerindeki ilk yıllarında yaşadıkları sorunlara ele aldıkları araştırmalarında 3 ana başlık altında topladıkları görülmektedir. Bunlar sırası ile "lisans eğitiminden kaynaklanan sorunlar", "yetersiz spor altyapısı" ve "beklenti ve uyum" sorunlarıdır. Lisans eğitiminden kaynaklanan sorunların başında; ortaokul ve lise ders programları hakkında hiç bilginin verilmemesi ve buna bağlı olarak programı anlamakta sorun yaşamaları gelmektedir. İlaveten, okul deneyimi uygulamasının amacını gerçekleştirememesi nedeniyle mesleğe başlanan ilk yıllarda öğretmenlerin kendilerini hazır hissetmediklerini, öğretim yöntemlerini teorik olarak gördüklerinden uygulamaya dönüştürememeleri nedeniyle ders işlenmesinde sorun yaşamışlardır. Lisans eğitiminde evrak işleyişinin nasıl olduğu tam belirtilmediğinde atandıkları okulda e-okul, günlük plan, zümre ile ilgili sorunlar yaşamalarına 
neden olmuştur. Bu sonuçlar lisans eğitiminin gücünü gözler önüne sermektedir. Altyapı başlığı altında yaşanan sorunlarda; yetersiz, kalitesiz malzeme, fiziksel koşullar nedenleriyle yıllık planda yer alan programların işleyemedikleri gelmektedir. Öğretmenler bu sorunu çözmek için spor kulübü adına para toplamak zorunda kaldıklarını ancak bu durumun ciddi bir stres faktörü olduğu belirtmişlerdir. Bunlara ek olarak literatürü destekleyen okul yönetiminin maddi ve manevi destek vermemesi ile okul yöneticileriyle diğer branş öğretmenlerinin dersi önemsemediklerini belirtmiş̧lerdir.

Uğraş ve Akbuğa'nın (2019) çalışmalarında öğretmenlerin \%20'sinin, öğrencilerinin ders sırasında yaralandığını belirtmiştir. Buda öğretmenler tarafından sürekli yaşanan güvenlik kaygısının nedeni olarak gösterilebilir. Öğretmenlerin kendi dersleri dışında da gerçekleşen yaralanmalarda kendilerine yönlendirdikleri belirtmişlerdir. Buda öğretmene yüklenen ilave ek rol olarak söylenebilir. Beden eğitimi öğretmenleri, özel araçları ile öğrencileri sağlık kuruşlarına götürdükleri, öğrencilere karşı sorumluluk hissettiklerinden dolayı devamlı bir kaygı içinde olduklarını belirtmişlerdir. Öğretmenlerin okullarında ilk yardım malzemesinin yetersizliğine değinirken, ecza dolaplarını kendilerinin doldurduklarını da eklemişlerdir. Herhangi bir yaralanmada takip edilecek işlem sırasının bilinmemesi karmaşaya neden olmakta ve öğretmenlerin kaygı seviyelerini yükseltmektedir. Maddi yetersizliklerden dolayı okul idaresi ise bu soruna çözüm üretememektedir. Öğretmenler lisans eğitimi sırasında ilkyardım eğitimini daha çok teorik olarak aldıklarını belirtmiştir. Uygulama sayısının arttırılması ve dersin niteliğinin arttırılması ileride yaşanacak olan sorunları engelleyebileceğini, hizmet içi eğitimlerde verilen seminerlerin ise daha çok uygulamaya dönük olması gerektiğini önemle vurgulamaktadırlar.

Kocayiğit ve Ekinci'nin (2020) inceledikleri araştırmalarında, maddi problemler kendini göstermektedir. Veliler tarafından ders dışı etkinlikler maddi bir yük olarak görüldüğünden öğrenci katılımları etkilenmektedir. Bunu bir yük olarak görmelerinin nedeni etkinliklere karşı olumsuz tutuma sahip olmaları ve taşımalı olarak gelen öğrencilerin ulaşımda yaşadıkları zorluklar olabilir. Fiziksel şartların ve malzeme eksikliği, ders saatinin fazlalığı öğretmenlerin yaşadıkları bir diğer sorunlar olarak belirtilmiştir.

\section{Farkı Ülkelerde Beden Eğitimi ve Spor Dersindeki Sorunlar}

Farklı ülkelerde yapılan beden eğitimi öğretmenlerinin karşılaştıkları sorunlara yönelik yapılan çalışmalara bakıldığında sorunların değişmediği görülmektedir. Dersin uygulanmasını engelleyen nedenlere bakıldığında; tesis ve malzeme eksikliği, ders saatinin azlığı, kalabalık sınıflar, sürekli güvenlik kaygısı, öğrencilerin disiplinsiz davranışları gelmektedir. Dolaylı nedenler incelendiğinde; branş öğretmenleri ile ilişkiler, velilerin olumsuz tutumları gelirken, dersin idare ve toplum tarafindan değersiz görülmesi, yaşanan iletişim çatışmaları ve öğretmenlere okuldaki mesleki görevleri dışında yüklenen ek roller gelmektedir. Lisans eğitiminin yetersizliği ve buna bağlı müfredata uymakta yaşanan zorluklar, istenilen evrakları hazırlamakta ve sahada uygulama sorunları ile kendinin gösterirken deneyim ve bilgi eksikliği de bir diğer nedendir. Hizmet içi eğitimlerin verimsiz olması meslek içinde kendilerini güncellemede sorunlar yaşamalarına neden 
olmaktadır (Al-Mohannadi ve Capel, 2007; Baek, Keath ve Elliott, 2018; Barroso, MccullumGomez, Hoelscher, Kelder, Murray, 2015; Blankenship ve Coleman, 2009; Eldar, Ayvazo, Talmor ve Harari, 2011; Gordon, 2016; Kulinna, Cothran ve Regualos, 2006; Mobarak Abedalhafiz, 2013; Mohr ve Townsend, 2001; Osborne, Belmont, Peixoto, Azeyedo, Carvalho Junior, 2016; Popeska vd.,2017; Sáenz-López, 2011; Shoval, Erlich ve Fejgin, 2010; Veloo ve Md-Ali, 2016; Villalba vd., 2017; Whipp, Tan ve Yeo, 2008).

Barroso vd., (2005) Teksas’ta yaptıkları çalışmada, iç ve dış alan tesis yetersizliğine dikkat çekerken aynı zamanda yeterli sayıda öğretmen olmadığının da altını çizmişlerdir. Ortak sorunlar arasında yer alan maddi ve manevi yetersiz destek bu çalışmada da kendini göstermektedir. İdarenin desteğinin olmaması gibi bununla birlikte dersin diğer branşlara göre statüsünün düşük olması birçok sorunun ana kaynağını oluşturmaktadır. Dersin finansal kaynağının yetersiz olması malzeme ve materyal eksikliğine neden olmaktadır. Sınıfların kalabalık olması ders işlenişini belirgin derecede etkilerken zaman yetersizliği göze çarpar bir şekilde ortaya çıkmaktadır.

McCaughtry, Barnard, Martin, Shen, Kullina' nın (2006) Amerika'da görev yapmakta olan öğretmenlerin yaşadıkları sorunları belirledikleri çalışmalarında öğretmenlerin; yetersiz malzeme ve kaynak ile uğraşmaları gerektiği aynı zamanda bulundukları şehrin kültürüne uygun eğitim vermeleri gerektiği için zorlandıkları belirlemiştir. Okul çevresinin etkisi bu araştırmada kendini göstermiştir. Örnek vermek gerekirse mülteci öğrencilerin yoğun olarak bulunduğu ve bölgede iletişim ve uyum sorunları yaşadıkları, bazı bölgelerde suç oranının yüksek olmasının öğrencilerin davranışlarına yansıdığını (olumsuz tavırlar, akran baskısı, zorbalık, tehdit edici davranışlar) belirlemişlerdir. Bunlara ek, müfredattın yetersiz olmasına gönderme yapılırken, daha fazla oyun eklenmesi gerektiğini belirtmiştir. Öğretmenlerin \%60’1 beden eğitimi dersinin bütçesinin olmadığını söylemiş, \%40'1 ise sadece yıllık 200 dolar bütçelerinin olduğunu ifade etmiştir. Araştırmaya katılan öğretmenler; kendi paraları ile malzeme aldığını, ekipmanları kendilerinin yaptığını, birçok öğretmenin ekipman bağışı için etkinlikler düzenlediği ya da yerel kulüpler ile görüsserek ikinci el ekipmanları almak için uğraştıklarını belirtmiştir. Öğretmenler, öğrencilere yardım etmelerini engelleyen bu sorunlardan dolayı görevlerini yerine getiremedikleri için kendilerini hüsrana uğramış, öfkeli ve suçlu hissetmektedirler. Özellikle lisans eğitimi sırasında gerçeğe karşı hazır olarak ayrılmadıkları için kültür şoku yaşandığını vurgulanmaktadır.

Jenkinson ve Benson (2010), Avustralya'da görev yapmakta olan beden eğitimi öğretmenlerinin ders işleme engellerinin dügüm noktasının tesislere, malzemelere ve eğitim alanına erişim olduğunu belirlemiş̧tir. Öğrencilerin derse karşı ilgilerinin düşük seviyede olduğu belirlenirken aynı zamanda derse katılan öğrencilerin ise akran baskısına maruz kalmalarının derse katılımı önemli derecede etkilediğini belirtmişlerdir. İlaveten yoğun müfredat, diğer branş öğretmenleri ve idareden yeterli destek görmediklerini de aynı şekilde ortaya koymuşlardır.

Shoval vd., (2010) mesleğe yeni başlayan öğretmenlerin fazla iş yükü nedeniyle zaman ve malzeme yönetiminde problem yaşadıklarını belirtmiştir. Öğrencilerin disiplinsiz davranışlarına 
değinilirken, lisans eğitiminden kaynaklı problemlerin (sınıf yönetimi, evrak işleri, müfredat gibi konulardaki rehberlik hizmetlerinin eksikliği, teori ve uygulamadaki boşluk vs.) meslek hayatına uyum sağlamakta sorunlar yaşamalarına neden olduğunu vurgulamışlardır.

Eldar vd., (2011) İsrail'deki beden eğitimi öğretmenlerinin yaptıkları çalışmada öğretmenler yaşadıkları sorunlarının nedenlerinin başında lisans eğitimi olduğunu belirtmişlerdir. Yeterli malzeme ve ekipmanla eğitim gördüklerini ancak kendilerinin gerçek koşullara karş1 eğitilmediklerini belirtmişlerdir. Şunu vurgulamakta yarar ki var ki yapılan her bir çalışma lisans eğitiminin önemini gözler önüne sermektedir. Bu çalışmada da öğretmenlerin birinci dereceden sorunlarının kaynağı lisans eğitime dayandırılmıştır.

Mäkelä, Hirvensalo ve Whipp'in (2014) Finlandiya'da ki çalışmalarının çıktılarına bakıldığında; öğretmenlerin, okul yönetimi tarafindan destek görmedikleri, iş yüklerinin fazla olduğu, ders programlarının yoğun olduğu, yeterli malzeme ve tesis eksikliğinin düş kırıklığına neden olduğunu, öğrencilerin derslere karşı ilgisiz olmalarının, basit hareketleri yapmakta bile zorlandıklarını, derse ya da öğretmenlere karşı saygılarının bulunmadığı, dersin statüsünün düşük olmasına bağlı olarak öğretmenlerin mesleklerinden ayrılmak istemelerine neden olduğu belirlenmiştir. Araştırmaya katılan öğretmenlerin \%39'unun işten ayrılmayı düşünmekte ya da düşündüğünü belirlemişlerdir. Çalışma koşulları ve statünün düşüklüğü öğretmenlerin iş doyumlarını etkilediği düşünüldüğünde bu düşünce geçmiş olması normal karşılanabilir.

Osborne vd., (2016) Brezilya'da yaptığı çalışmalarında lisans eğitimi ve uygulamadaki uyumsuzluklara değinmiştir. Teorik derslerin pratiğe aktarılmasında sorunlar yaşanmaktadır. Öğretmenler kötü çalışma şartlarında çalıştıklarını belirlemişlerdir. Derste yaşanan sorunlara bakıldığında yetersiz malzeme, düşük bütçeye sahip olma, okul yönetimi ve hükümetten yeteri destek görmediklerini belirtirken aynı zamanda dersin yeterli değeri görmediğini de ifade etmişlerdir. Kalabalık sınıflar ve öğrencilerin disiplinsiz davranışlarında çalışmada kendini gösteren sorunlar arasında yer almaktadır.

Gordon'un (2016) mesleğe yeni başlayan, öğretmenlik bölümü ve formasyon gibi alternatif öğretim programından mezun olan öğretmenlerle yaptığı çalışmasında, mesleğe kendilerini tam olarak hazır hissederek başlamadıklarını belirtmişlerdir. Alternatif programdan mezun olan katılımcı, sınıf yönetimi dersini aldığını ancak genel ve daha çok teoriye dayalı ders aldığı sınıf yönetim ve organizasyonunda sorun yaşadığını belirtmiştir. Öğretmenler genel olarak teoriye dayalı bilgiler almalarının saha da uygulamada sorunlar neden olduğunu, öğretmenlerin nitelikleri, zaman yönetimi, disiplin, aile-öğretmen ilişkilerinde, edindikleri bilgilerini nasıl aktaracaklarını bilemediklerini ve öğrencilerin güvenliklerinden endişe duydukları (kanayan burunlar, düşmelere bağlı morluklar, çizikler, kırık ve çıkıklar gibi) vurgulamışlardır.

Veloo ve Md-Ali 'nın (2016) Malezya'da görev yapmakta olan beden eğitimi uygulamada karşılaştıkları sorunlar üzerinde yaptıkları çalışmanın sonuçları literatürdeki diğer çalışmaları 
desteklemektedir. Mesleki sorunların temel nedenlerinden biri olan lisans eğitimi gösterilmektedir. Önceki araştırmalar gibi bu çalışmada öğretmenlerin en problem yaşadıkları alanlar yetersiz malzeme ve olumsuz fiziki şartlardır. Benzeri şekilde sınıf yönetimi ve alan bilgisi nedeniyle de ders işlemekte sorunlar yaşadıklarını bildirmişlerdir.

Popeska vd., (2017) Makedonya'da görev yapmakta olan beden eğitimi öğretmenlerinin uygulama sürecinde karşılaştıkları sorunlar üzerine yaptıkları çalışmanın doğrultusunda, ders işlenme engellerinin başında dersin verimliliğini kayda değer biçimde etkileyen malzeme, materyal ve fiziki alanlar gelmektedir. $\mathrm{Bu}$ araştırma ile öğretmenler bu alanlarda sorun yaşadıklarını belirtmişlerdir. Literatürde belirtilen ortak sorunlardan farklı olarak her bir okulun politikalarının farklılık göstermesi ve mevcut müfredatın öğretmenlerin sorunlarının başında gelmektedir. Bütün bu nedenler düşünüldüğünde dersten istenilen verimin elde edilememesi doğal görülmektedir.

Baek vd., (2018) beden eğitimi öğretmenlerinin teknolojiyi kullanma düzeyleri ile karşılaştıkları engelleri araştırdıkları çalışmalarında, öğretmenlerin teknolojiyi kullanmayı istedikleri ancak yeterli düzeyde bilgiye sahip olmadıkları belirlenirken aynı zaman da bu yönde herhangi bir eğitim almamış olmaları karşılaştıkları sorunların temelini oluşturmuştur. Teknolojinin hızla ilerlediği düşünüldüğünde lisans eğitimlerinde teknoloji eğitiminin de verilmesi gerektiği düşünülmektedir.

Zach, Dunsky, Stein, Litvin, Hellerstein'nin (2020) İsrail'de mesleğe yeni başlayan beden eğitimi ve spor öğretmenlerine yönelik yaptıkları çalışmada, öğretmenlerin eğitimleri sırasında teorik bilgileri yoğun olarak gördükleri ancak benzeri şekilde uygulamayı daha az görmüş olmalarının saha da birtakım sorunlara neden olduğunu belirlemişlerdir. Bu durum mesleğe uyum aşamasının zorlaşmasına, gerçeklik şoku yaşamalarına ya da hazırlıksız hissetmelerine neden olmaktadır. Aldıkları teorik eğitim ve saha uygulaması arasında büyük boşluk bulunmaktadır. Bunlara ek olarak kalabalık sınıflar, fazla iş yükü, malzeme ve tesis eksiklikleri, yetersiz uygulama deneyiminin sorunlara neden olduğunu ifade etmişlerdir.

Von Haaren-Mack, Schaefer, Pels ve Kleinert'in (2020) çalışmasında ders engellerinin başında belirgin derecede malzeme, ekipman ve tesis yetersizliği gelmektedir. Ayrıca öğrencilerin disiplinsiz davranışlar sergilenmesi, sürekli güvenlik kaygısı yaşanması, velilerle olan iletişim sorunları olduğu görülmektedir. İş yükünün fazla olması, müfredat programları, beden eğitimi dersinin statüsünün diğer derslere göre düşük olması, maaşın yeterli seviyede olmadığı düşünceleri öğretmenler tarafından ana stres faktörleri olarak belirlenirken motivasyon eksikliği ile sonuçlandırmaktadır. 
Temiz, C.N. ve Sivrikaya, A.H. (2021). Beden eğitimi ve spor dersinde karş̧laşılan sorunların incelenmesi (Yurt içi ve yurt dışı değerlendirmesi). Avrasya Spor Bilimleri ve Ĕ̈itim Dergisi, 3(1), 12-39.

\section{TARTIŞMA VE SONUÇ}

Beden eğitimi ve spor dersi çocukların özgürce hareket etmesinin sağlandığı ve gelişimlerinin desteklendiği bir derstir. Ancak akademik başarı hevesi, çocukların hareket etmelerini engellemekte boşa kalan zamanlarında ders çalışmaya itmekte hatta zorlamaktadır. Hareketsiz yaşam her yaş grubu için tehlike alarmının çalınmasına işarettir. Çocukluk dönemindeki hareketsizlik, yaşamın ilerleyen dönemlerinde sorunlarla ortaya çıkmaktadır. Vücut, özellikle de bebeklik ve çocukluk döneminde hareket ederek gelişir. Hareket etme çocukluk sürecinde mutluluk kaynağının temelidir. Bu nedenle özellikle erken çocukluk döneminde çok hareketli olan çocukların hareket etmeleri ebeveynleri tarafından kısıtlanmamalıdır. Bilakis, gelişimlerinin önemli bir parçası olarak görülüp, hareket alanı ve çeşitliliği artırılmaya çalışılmalıdır (Orhan, 2019).

Beden eğitimi ve spor dersi, temel bilimlerin aksine akademik başarının ön planda olmadığı, özel yetenek ve ilgiye dayanan bir ders olarak görülmektedir. Ancak çalışmalar, dersin "yüksek puanla geçilmenin zorunlu" olduğu aksi takdirde idare, veli ve öğrenciler tarafından baskılara maruz kalınacağına işaret etmektedir. Öğretmenler, toplum tarafından düşük not verilemeyeceği algısı nedeniyle not baskısından kaçınmaya çalışmakta lakin ölçme değerlendirme basamaklarını bilmemeleri, uygulayamamaları, bir kılavuza sahip olmamaları, kendilerini güncelleyememeleri için yüksek not verme eğiliminden kurtulamamaktadır. Sonuçta bu durum dersin statüsünü etkilemektedir. Beden eğitimi ve spor dersi ve öğretmenlerinin, diğer branş öğretmenleri, idareciler, veliler ve öğrenciler tarafından diğer dersler gibi değer görmediği ortadır. Ancak unutulmamalıdır ki, beden eğitimi dersinin itibarinin geri kazandırılması yine öğretmenlerimize düşmekte, kendilerini güncelleyen, yeniliklere açı, teknoloji takip eden, uygulayabilen ve girişken bireyler olarak mesleğe ilk başladıkları anda ki ruh ve azimlerini kaybetmemeleri gerekmektedir. Uzun zamana yayılması gereken yeni ve işleyen iyileştirme; yapılandırma politikalarına ihtiyaç duyulmaktadır. Beden eğitimi dersleri, klasik olarak dört duvar arasında işlenen bir ders değildir. Bu nedenle daha fazla kaynağa ihtiyaç duymaktadır. Kaynak ve malzeme eksikliği dersin işlenmesindeki en büyük engeldir. Tesis ve malzemeler, kullanıma bağlı olarak her y1l yenilenmesi ya da yenisinin alınması gerektiğinden ekonomik olarak okullara büyük bir yük bindirmektedir. Kısıtlı bütçeye sahip olan okullarda idare tarafindan sorunlar biliniyor ve kabul ediliyor olmasına karşın kayda değer bir değişim gerçekleştirilememektedir. Şunu vurgulamakta fayda vardır ki politika yapıcılarının bu sorununun etkilerine en aza indirmeleri için ivedilik ile harekete geçmesi gerekmektedir. Öğretmenler bulundukları yerlerde belli bir süre kendi maaşları ile malzeme almakta, yenilemekte, sponsor aramakta, ikinci el malzemeleri bulmaya çalışmakta, bütçeye göre kalitesiz ürün almak zorunda kalmaktadırlar oysa bunlar kısa vadeli çözümlerdir.

Her geçen gün bilgiler hızla güncellenmekte ve teknolojik gelişmeler gittikçe eğitimle iç içe olmaya başlamaktadır. Dijital çağ hızla ilerlemekte ve bu gelişmeleri yakalayıp uygulayabilen öğretmenlere sahip olmamız gerekmektedir. Hizmet içi eğitimler ve seminerler ile öğretmenlerin 
kendilerini güncelleyebilecekleri ve eksik oldukları alanlarda kendilerini doldurabilecekleri bir çalışma alanı olmalıdır. Öğretmenlere yönelik hizmet içi eğitim; eğitim ve öğretim hedeflerinin öğrencilere kazandırılması sürecinde gerek duyulan bilgi, beceri, tutum ve davranışların bilimsel yöntemlerle öğretmenlere kazandırılmasını amaçlayan süreçleri ifade eder (Aslan, Göksu ve Karaman, 2018). Bu nedenle hizmet içi eğitimler program çıktılarının istendiği gibi elde edilmesi açısından oldukça önemlidir. Yapılan çalışmalara bakıldığında hizmet içi eğitimlerin verimsiz olduğu belirlenirken bununla birlikte öğretmenler tarafindan yetersiz olarak tanımlanmaktadır. Yapılan araştırmalar gösteriyor ki öğretmenler ve öğretmen adaylarının öğretmen merkezli ve belli başlı yöntemleri tercih ediyor (Aktop ve Karahan, 2012; Cengiz ve Serbes, 2014; Şirinkan ve Erçiş, 2009; Yıldız ve Kangalgil, 2014) alanın en önem teşkil eden ve bir o kadar problemli yeri ölçme ve değerlendirme aşamasını ise "gereksiz, evrak işi, evrak yükü, saha da uygulanamaz" olarak görmektedirler. Yetersiz hizmet içi eğitim, bilgilendirme, yönlendirmelerin yapılmamasından kaynaklandığg düşünülmektedir. Öğretmen adaylarının eğitimleri sırasında öğretmen merkezli uygulamalara maruz kalmaları mesleğe ilk adım attıklarını öğretmen merkezli uygulamaları kullanmalarına yöneltmektedir. Öğretmenler programlardan mezun olmadan önce gerçeklik şoku yaşamamaları için sahaya uygun olarak yetiştirilmelidir. Öğretmen adayları, karşılaşacakları engellere karşı duygusal olarak da gerçeklere karşı hazırlanmalıdır. Öğretmen adayları tarafından en gerekli derslerin başında okul deneyimi ve öğretmenlik uygulaması gelmektedir. Staj eğitimlerinin niteliği ile orantılı olarak ders sayısının arttırılması, dönemlere ayrılması öğretmen adaylarının mesleğe gerçekçi yaklaşmasını sağlayabilir. Öğretmen yetiştiren kurumların saha çalışmalarına, uygulamalarına verdikleri önem arttırılmalı, pedagojik derslerin geliştirilmesi ve iyileştirilmesi için ek düzenlemeler getirilmelidir. Öğretmen Eğitimi Programlarının, daha etkili olması gerektiği, geleceğe ve gerçeklere hazır halde mezun vermeleri gerekmektedir.

Çalışma koşullarının sağlıklı olmaması öğretmenleri mesleklerinden uzaklaşmaya iterek mesleklerini bırakma derecesine getirmektedir. Öğretmenler duygusal olarak kendilerini yetersiz hissettikleri gibi yoğun stres, düş kırıklığı, üzüntü yaşamaktadırlar. Bu durum mesleki ve duygusal tükenmişlik seviyelerinin artmasına, başarısızlık hissi ile iş ve yaşam doyumlarının düşmesine sebep olmaktadır. Mesleğe yeni başlayan öğretmenler için bunlara ek olarak lisans eğitimi ve uygulama arasındaki boşluk, mesleğe hazır olarak başlayamamalarına neden olarak gerçeklik şoku yaşatmaktadır (Al-Mohannadi ve Capel, 2007; Demirhan, 2016; Kelgökmen, Uzunöz, 2016; Kıral ve Diri, 2016; Tekkurşun Demir, İlhan ve Cicioğlu, 2018; Uğraş vd., 2019; Von Haaren-Mack vd., 2020). Eğitim çıktılarının elde edilmesinde öğretmenlerin performanslarının en önemli faktör olduğu düşünüldüğünde öğretmenlerin çalışma koşullarının düzenlenmesi, stres yaratan nedenlerin en aza indirilmesi son derece önem arz etmektedir. Özellikle mesleğe yeni başlayan öğretmenlerin deneyim eksikliğine bağlı olarak sorunların üzerinden gelmeleri daha güç olduğundan risk grubunda yer almaktadırlar. Öğretmenlerin meslekleri ile ilgili var olan sorunlarının giderilmesi ve mesleklerine yönelik beklentilerinin karşılanması onların daha az tükenmişlik yaşamalarını, işlerinden daha çok doyum almasını sağlayacaktır (Karaaslan, Uslu ve Esen, 2020). Öğretmenler yaşadıkları bu problemlerin dersin akışını engellediği, dersin niteliğini düşürdügü, bunun sonucunda öğrenciler, veliler ve diğer branş öğretmenlerinin dersi gereksiz 
algılamalarına neden olduğu böylece mesleğe olan saygının azaldığı ve bu durumun öğretmenlerin motivasyonunu olumsuz yönde etkilediğini dile getirmektedirler (Yılmaz vd., 2018).

$\mathrm{Bu}$ araştırmada beden eğitimi öğretmenlerinin meslek yaşamında yaşadıkları sorunlar incelenerek literatüre farklı bir bakış açısı kazandırmaya çalışılmıştır. Öğretmenlerin problemlerinin büyük çoğunluğu; almış oldukları lisans eğitiminin, hizmet içi eğitimlerin yetersizliği, idare, branş öğretmenleri, veliler tarafindan yeterli destek görülmediği, dersin ve mesleğin statüsünün düşük olmasından kaynaklanırken dersin işlenmesindeki en büyük engeller tesis, malzeme eksikliği, kalabalık sınıflar, zaman yetersizliği, dersin akademik olarak etki etmemesine bağlı sorunlardan oluşmaktadır. Sonuç olarak, öğretmenler tarafindan ifade edilen sorunlar en baştan en son ki aşamasına kadar iletilmeye çalışılmıştır. Önemle belirtmek gerekir ki bu sorunlar kronik hale gelmeden önce, acil önem arz ettiğinden bir an evvel harekete geçilmelidir. Bu çalışmadaki bilgilerin; yasa ve program yapıcıların ileride yapabilecekleri çalışmalarına katkı sağlayacağı, iyileştirme ve yapılandırma çalışmalarının neler üzerinden yoğunlaştırılması gerektiği yönünden aydınlatacağı düşünülmektedir.

\section{ÖNERILLER}

- Lisans Programları ve MEB ders içeriklerinin paralel olması gerekmektedir.

- Ders saatinin arttırılması, malzeme ve materyal desteğinin sağlanması, Beden eğitimi dersinin işlene bilirliğini arttıracaktır.

- Beden eğitimi dersinin ölçme değerlendirme basamağı standardize edilmeli, "dersin kolay geçilebilir ders" algısından çıkartılmalı ve gerçekçi sonuçlar elde edilmelidir.

- Okul deneyimi, öğretmenlik uygulaması gibi saha da çalışma imkânı veren derslerin ders saatleri arttırılmalı ve etkinliği kontrol edilmelidir.

- Hizmet içi eğitimlerin önemi arttırılmalı ve denetlenmesi sağlanmalıdır.

- Mesleğe yeni başlayan öğretmen adayları için danışmanlık programlar başlatılmalıdır.

- Uygulamalı derslerin içeriği arttırılmalı, teorikte ve pratikte farklılık yaratan konu ve derslerin düzenlenmesi yapılarak gerçeğe daha yakın hale getirilmelidir.

- Yerel yönetimlerin malzeme desteği sağlamasına yönelik çalışmalar yapılmalı ve okulların ortak tesis, malzeme kullanımının yolu açılmalıdır. 
Temiz, C.N. ve Sivrikaya, A.H. (2021). Beden eğitimi ve spor dersinde karş̧laşılan sorunların incelenmesi (Yurt içi ve yurt dışı değerlendirmesi). Avrasya Spor Bilimleri ve Ĕ̈itim Dergisi, 3(1), 12-39.

\section{KAYNAKLAR}

Aka, S., Arı, E., Can, İ. ve Kale, R. (2011). Beden eğitimi ve spor öğretmenlerinin beden eğitimi ve spor derslerinde verdikleri notların yorumlanması üzerine bir araştırma. Yüzüncü Yıl Üniversitesi Eğitim Fakültesi Dergisi, 8 (özel), 62-72.

Aktop, A. \& Karahan, N. (2012). Physical education teacher's views of effective teaching methods in physical education. Procedia-Social and Behavioral Sciences, 46, 1910-1913. DOI: 10.1016/j.sbspro.2012.05.401.

Alagül, Ö. ve Gürsel, F. (2018). Beden eğitimi öğretmenlerının pedagojık yenılık öğrenırken çalışma koşullarının rolü. S. Dinçer (Ed.), Değişen Dünyada Eğitim içinde (385-395). Ankara: Pegem Akademi.

Al-Mohannadi, A. \& Capel, S. (2007). Stress in physical education teachers in Qatar. Social Psychology of Education, 10, 55-75. DOI: 10.1007/s11218-006-9004-9.

Aslan, A., Göksu, İ. ve Karaman, S. (2018). Uyarlanabilir uzaktan hizmetiçi eğitimin başarı ve eğitimin tamamlama süresine etkisi ile öğretmen görüşleri. Dokuz Eylül Üniversitesi Buca Eğitim Fakültesi Dergisi, (45), 103115.

Asma, M., Çamlıyer, H., Soytürk, M., Balc1, T. ve Çamlıyer, H. (2018). An ınvestigation on alternative measurement and evaluation in physical education and sport teaching. Sakarya University journal Of Education, 8(3), 3762. DOI: $10.19126 /$ suje.398201.

Atasoy, M. (2008). Beden eğitimi öğretmenlerinin mesleki sorunlarının araştırılması ve çözüm önerileri (kırşehir ili örneği). Yüksek lisans tezi, Gazi Üniversitesi, Sağlık Bilimleri Enstitüsü, Ankara.

Avşar, Z. (2009). İlköğretim öğrencilerinin beden eğitimi dersi değerlendirme süreci ile ilgili görüşlerinin belirlenmesi. Spor Bilimleri Dergisi, 20(3), 81-89.

Aydoğan, H. Beden eğitimi öğretmenlerinin, meslekte karşılaştıkları problemlerinin, aldıkları eğitim yönünden, okul ve fiziki şartlar çerçevesinde, strese neden olma boyutunun demografik özellikleri açısından incelenmesi. Yüzüncü Yıl Üniversitesi Eğitim Fakültesi Dergisi, 8(özel), 1-8.

Baek, J.-H., Keath, A. \& Elliott, E. (2018). Physical education teachers' technology practices and challenges. Internatıonal Journal Of Human Movement Science, 12(2), 27-42. DOI: 10.23949/ijhms.2018.08.12.2.2.

Barroso, C. S., Mccullum-Gomez, C., Hoelscher, D. M., Kelder, S. H. \& Murray, N. G. (2005). Self-reported barriers to quality physical education by physical education specialists in texas. Journal Of School Health, 75(8), 313-319. DOI: 10.1111/j.1746-1561.2005.00042.x.

Baxter-Jones, A. D., Maffulli, N. \& Toya Study Group (2003). Parental influence on sport participation in elite young athletes. The Journal Of Sports Medicine And Physical Fitness, 43(2), 250-255.

Blankenship, B. T. \& Coleman, M. M. (2009). An examination of "wash-out" and workplace conditions of beginning physical education teachers. Physical Educator, 66(2), 97-111.

Bulca, Y., Saçlı, F., Kangalgil, M. ve Demirhan, G. (2012). Beden eğitimi öğretmenlerinin öğretmen yetiştirme programına ilişkin görüşleri. Eğitim ve Bilim, 37(165). 82-92.

Cengiz, C. ve Serbes, Ş. (2014). Türkiye'deki beden eğitimi öğretmen adaylarının tercih ettikleri öğretim stilleri ve stillere ilişkin değer algıları. Pamukkale Journal Of Sport Sciences, 5(2). 21-34.

Chatoupis, C. C. (2018). Physical education teachers' use of mosston and ashworth's teaching styles: a literature review. Physical Educator, 75(5), 880-900. DOI: 10.18666/TPE-2018-V75-I5-8292. 
Temiz, C.N. ve Sivrikaya, A.H. (2021). Beden eğitimi ve spor dersinde karş̧laşılan sorunların incelenmesi (Yurt içi ve yurt dışı değerlendirmesi). Avrasya Spor Bilimleri ve Ĕ̈itim Dergisi, 3(1), 12-39.

Çınar, H. (2011). Sivas il merkezindeki ilköğretim okullarında görev yapan beden eğitimi öğretmenlerinin ders dlşı egzersiz çalışmalarında karşılaştıkları sorunların incelenmesi. Yüksek lisans tezi, Cumhuriyet Üniversitesi, Sağlık Bilimleri Enstitüsü, Beden Eğitimi ve Spor Ana Bilim Dalı, Sivas.

Çolakoğlu, T. ve Karaküçük, S. (2006). Beden eğitimi öğretmenlerinin okullarda uygulamada karşılaştıkları sorunlar üzerine bir araştırma. Gazi Beden Eğitimi ve Spor Bilimleri Dergisi, 11(3), 35-48.

Demir, M. (2018). Beden eğitimi ve spor öğretmenlerinin mesleki sorunlarl ve performanslarına etkileri Adıyaman ili örneği. Yüksek lisans tezi, Bartın Üniversitesi, Eğitim Bilimleri Enstitüsü, Beden Eğitimi ve Spor Öğretmenliği Ana Bilim Dalı, Bartın.

Demirci, A. (2013). Beden eğitimi ve spor ögrretiminde öğretim teknolojileri ve materyal tasarımı. Ankara: Nobel.

Demirhan, G., Bulca, Y., Altay, F., Şahin, R., Güvenç, A., Aslan, A., Güven, B., Kangalgil, M., Hünük, D., Koca, C. ve Açikada, C. (2008). Beden eğitimi öğretim programları ve programların yürütülmesine ilişkin paydaş görüşlerinin karşılaştırılması. Spor Bilimleri Dergisi, 19(3), 157-180.

Doğar, Y. (2019). İlköğretim okullarında beden eğitimi ve spor dersinin okutulmasında okul içi spor tesis, araç ve gereçlerin yeterlilikleri ve mahalli spor imkânlarından yararlanma durumu (niğde örneği). Beden Eğitimi Ve Spor Bilimleri Dergisi, 21(2), 70-80.

Eldar, E., Ayvazo, S., Talmor, R. \& Harari, I. (2011). Difficulties and successes during induction of physical education teachers. International Journal of Physical Education, XLVIII(1), 33-42.

Erbaş, M. ve Ünlü, H. (2012). Beden eğitimi öğretmenlerinin öğretmenlik öncesi hazırlık sürecinde yer alan derslere ilişkin görüşleri. Beden Ĕgitimi ve Spor Bilimleri Dergisi, 6(2), 200-206.

Erhan, S. E. ve Tamer, K. (2009). Doğu anadolu bölgesi ilköğretim ve ortaöğretim okullarında beden eğitimi dersi için gereken tesis araç-gereç durumları ile öğrencilerin beden eğitimi dersine ilişkin tutumları arasındaki ilişkiler. Atatürk Üniversitesi Beden Eğitimi Ve Spor Bilimleri Dergisi, 11(3), 57-66.

Erhan, S.E. (2009). Doğu anadolu bölgesi il merkezlerinde beden eğitimi dersinin işlenebilirliği, beden eğitimi ögretmenlerinin sorunlarl ve bunların ögrenci tutumları üzerine etkisi. Doktora tezi, Gazi Üniversitesi, Eğitim Bilimleri Enstitüsü, Beden Eğitimi ve Spor Öğretmenliği Ana Bilim Dalı, Ankara.

Gordon, E. J. (2016). Concerns of the novice physical education teacher. The Physical Educator, 73(4), 652-670. DOI: 10.18666/TPE-2016-V73-I4-7069.

Gökyer, N. (2011). İlköğretim okulu zümre öğretmenler kurulu toplantılarının gerçekleşme düzeyi. Fırat Üniversitesi Sosyal Bilimler Dergisi, 21(2), 127-148.

Güllü, M., Güllü, E. ve Güllü, A. (2009). İlköğretimde çalışan beden eğitimi öğretmenlerinin yapılandırmacı yaklaşıma ve beden eğitimi dersi yeni öğretim programına ilişkin görüşlerinin incelenmesi. Kafkas Üniversitesi Sosyal Bilimler Enstitü Dergisi, 1(3), 207-219.

Gülüm, V. ve Bilir, P. (2011). Beden eğitimi öğretim programının uygulanabilme koşulları ile ilgili beden eğitimi öğretmenlerinin görüşleri. Spormetre Beden Eğitimi ve Spor Bilimleri Dergisi, 9(2), 57-64. DOI: 10.1501/Sporm_0000000200 .

Güven, P. ve Öncü, A. (2006). Beden eğitimi ve spora katılımda aile faktörü. Sosyal Politika Çalışmaları Dergisi, 10(10), 81-90.

Harwood, C. G. \& Knight, C. J. (2016). Parenting in sport. Sport, Exercise, And Performance Psychology, 5(2), 8488. DOI: $10.1037 /$ spy0000063.

Hekim, M. (2016). Çocuklarda beden eğitimi, spor ve oyun etkinliklerine katılımın kemik gelişimi üzerine etkilerinin değerlendirilmesi. Gümüşhane Üniversitesi Sağllk Bilimleri Dergisi, 5(2), 66-71. 
Temiz, C.N. ve Sivrikaya, A.H. (2021). Beden eğitimi ve spor dersinde karş̧laşılan sorunların incelenmesi (Yurt içi ve yurt dışı değerlendirmesi). Avrasya Spor Bilimleri ve Ĕ̈itim Dergisi, 3(1), 12-39.

Hoşkilimci, A. (2011). Kamu ve özel okullarda çalışan beden eğitimi öğretmenlerinin karşılaştıkları sorunların araştırması (Sarlyer ilçesi örneği). Yüksek lisans tezi, Yeditepe Üniversitesi, Sosyal Bilimler Enstitüsü, Eğitim Yönetimi ve Denetimi Ana Bilim Dalı, İstanbul.

Jaakkola, T. \& Watt, A. (2011). Finnish physical education teachers' self-reported use and perceptions of mosston and ashworth's teaching styles. Journal of Teaching in Physical Education, 30(3), 248-262. DOI: 10.1123/jtpe.30.3.248.

Jenkinson, K. A. \& Benson, A. C. (2010). Barriers to providing physical education and physical activity in victorian state secondary schools. Australian Journal Of Teacher Education, 35(8). DOI: 10.14221/ajte.2010v35n8.1.

Kangalgil, M. ve Özgül, F. (2019). Öğretmenlik uygulaması dersi ile ilgili öğretmen görüşlerinin incelenmesi. Electronic Turkish Studies, 14(4), 2469-2481. DOI: 10.29228/TurkishStudies.22710.

Kangalgil, M., Hünük, D. ve Demirhan, G. (2006). İlköğretim, lise ve üniversite öğrencilerinin beden eğitimi ve spora ilişkin tutumlarının karşılaştırılması. Spor Bilimleri Dergisi, 17(2), 48-57.

Karaaslan, İ., Tuna, U. S. L. U. ve Serkan, E. S. E. N. (2020). Beden eğitimi öğretmenlerinin mesleki tükenmişlik, iş doyumu ve yaşam doyumlarının incelenmesi. Journal of Health and Sport Sciences, 3(1), 7-18.

Karabulutlu, Z. ve Pulur, A. (2017). Beden eğitimi öğretmenlerinin mesleki yeterliği ve eğitimlerinin özel alan yeterliklerine etkisinin incelenmesi. Spormetre Beden Eğitimi Ve Spor Bilimleri Dergisi, 15(3), 171-176. DOI: 10.1501/Sporm_0000000322.

Karaküçük, S. (1999). Okul yöneticilerinin ders dışı etkinliklere yaklaşımları. Gazi Beden Eğitimi ve Spor Bilimleri Dergisi, 4(3), 51-62.

Karaçam, A. ve Pulur, A. (2016). Beden eğitimi öğretmenlerinin başarı algısı, akademik iyimserlik, psikolojik iyi oluş ve fiziksel saygı düzeylerinin incelenmesi. Uşak Üniversitesi Eğitim Araştırmaları Dergisi, 3(1), 1-22.

Kelgökmen, A., Uzunöz, F. ve Demirhan, G. (2016). Beden eğitimi öğretmenlerinin tükenmişlik düzeylerinin saptanması ve karşılaştııılması. Kastamonu Ĕgitim Dergisi, 24(3), 1503-1516.

Keske, G. (2007). Illköğretim okullarında görev yapan beden eğitimi öğretmenlerinin kullandıkları öğretim yöntemleri ve karşılaştıkları sorunlar. (Gaziantep ili örneği). Yüksek lisans tezi, Çukurova Üniversitesi, Sağlık Bilimleri Enstitüsü, Beden Eğitimi ve Spor Ana Bilim Dalı, Adana.

Kılıçaslan, U. Ve Baş, M. (2020). Beden eğitimi ve spor dersi öğretim programında yapılan değiş̧ikliklere öğretmenlerin bakış açısı. Beden Eğitimi ve Spor Bilimleri Dergisi, 22(3), 100-108.

Kıral, E. ve Diri, M. (2016). Ortaokul öğretmenlerinin iş doyumlarının mesleki tükenmişlik düzeylerine etkisi. Mehmet Akif Ersoy Üniversitesi Ĕ̈itim Fakültesi Dergisi, 1(39), 125-149. DOI: 10.21764/efd.81587.

Kırekin, T. (2016). Van ilinde görev yapan beden eğitimi öğretmenlerinin beden eğitimi ve spor dersinin etkinliği üzerine görüşlerinin incelenmesi. Yüksek lisans tezi, Yüzüncü Y1l Üniversitesi, Eğitim Bilimleri Enstitüsü, Beden Eğitimi ve Spor Ana Bilim Dalı, Van.

Kızılkaya Namlı, A. ve Temel, C. (2019). Beden eğitimi ve spor öğretmenliği lisans programının değerlendirilmesi ve program önerisi. Milli Eğitim Dergisi, 48(1), 321-351.

Kocayiğit, A. ve Ekinci, N. (2020). Ortaöğretim okullarında uygulanan program dış1 etkinliklerin öğretmen görüşlerine göre değerlendirilmesi. Opus Uluslararası Toplum Araştırmaları Dergisi, 16(29), 1-1. DOI: 10.26466/opus.749109. 
Temiz, C.N. ve Sivrikaya, A.H. (2021). Beden eğitimi ve spor dersinde karş̧laşılan sorunların incelenmesi (Yurt içi ve yurt dışı değerlendirmesi). Avrasya Spor Bilimleri ve Ĕ̈itim Dergisi, 3(1), 12-39.

Konukman, F., Agbuĝa, B., Erdoĝan, Ş., Zorba, E., Demirhan, G. \& Yilmaz, I. (2010). Teacher-coach role conflict in school-based physical education in USA: a literature review and suggestions for the future. Biomedical Human Kinetics, 2(1), 19-24. DOI: 10.2478/v10101-010-0005-y.

Kul, M. ve Hergüner, G. (2018). Beden eğitimi ve spor öğretmenlerinin sorunları ve performanslarına etkileri (Sakarya ili örneği). Abant İzzet Baysal Üniversitesi Ĕgitim Fakültesi Dergisi, 18(2), 971-996. DOI: 10.17240/aibuefd.2018..-400744.

Kulinna, P. H., Cothran, D. J. \& Regualos, R. (2006). Teachers' reports of student misbehavior in physical education. Research Quarterly for Exercise and Sport,77(1), 32-40. DOI: 10.1080/02701367.2006.10599329.

Mäkelä, K., Hirvensalo, M. \& Whipp, P. R. (2014). Should I stay or should I go? Physical education teachers' career intentions. Research Quarterly For Exercise And Sport,85(2), 234-244. DOI: 10.1080/02701367.2014.893052.

Marshall, J. \& Hardman, K. (2000). The state and status of physical education in schools in international context. European Physical Education Review, 6(3), 203-229. DOI: 10.1177/1356336X000063001.

McCaughtry, N., Barnard, S., Martin, J., Shen, B. \& Kulinna, P. H. (2006). Teachers' perspectives on the challenges of teaching physical education in urban schools: The student emotional filter. Research Quarterly For Exercise and Sport, 77(4), 486-497. DOI: 10.1080/02701367.2006.10599383.

MEB. (2018). Ortaokul 5,6,7 ve 8. sınıflar beden eğitimi ve spor dersi öğretim programı. Erişsim tarihi; 18.12.2020, www.meb.gov.tr.

MEB. (2018). Ortaöğretim 9,10,11 ve 12. sınıflar beden eğitimi ve spor dersi öğretim programı. Erişim tarihi; 18.12.2020, www.meb.gov.tr.

Mercan, U. (2020). Aksaray'da görev yapan beden ĕgitimi ve spor öğretmenlerinin alternatif ölçme değerlendirme yöntem ve araçlarını kullanabilme yeterlikleri, karşılaş̧tıları sorunlar ve çözüm önerileri. Yüksek lisans tezi, Aksaray Yıl Üniversitesi, Sosyal Bilimler Enstitüsü, Beden Eğitimi ve Spor Ana Bilim Dalı, Aksaray.

Mirzeoğlu, A. D. (2017). Model temelli beden eğitimi öğretimi. Ankara: Spor Yayınevi.

Mirzeoğlu, A. D., Yaralı, S. S., Çoknaz, D. ve Özmen, S. (2019). Beden eğitimi ve spor öğretmenlerinin gözünden dersleri ve meslekleri (sakarya örneği). Gazi Beden Eğitimi ve Spor Bilimleri Dergisi, 24(2), 111-131.

Mirzeoğlu, D. (2013). Eğitim (pedagoji) temelleri. N. Mirzeoğlu (Ed.), Spor Bilimlerine Giriş içinde (95). Ankara: Spor Yayınevi.

Mobarak Abedalhafiz, A. (2013). Obstacles face physical education at schools in Al Madenah Al MunawarahKSA. European Scientific Journal, 9(13), 284-300. DOI: 10.19044/esj.2013.v9n13p\%p.

Mohr, D. J. \& Townsend, J. S. (2001). In the beginning: new physical education teachers' quest for success. Teaching Elementary Physical Education, 12(4), 9.

Oğul, E.O. (2010). Beden eğitimi ve spor mesleki açıdan karş̧laş̧tı̆̆ sorunlar (Balıkesir il örneği). Yüksek lisans tezi, Gazi Üniversitesi, Sağlık Bilimleri Enstitüsü, Beden Eğitimi ve Spor Ana Bilim Dalı, Ankara.

Orhan, R. (2019). Çocuk gelişiminde fiziksel aktivite ve sporun önemi. Kırlkkale Üniversitesi Sosyal Bilimler Dergisi, 9(1), 157-176.

Osborne, R., Belmont, R. S., Peixoto, R. P., Azevedo, I. O. S. De. \& Carvalho Junior, A. F. P. De (2016). Obstacles for physical education teachers in public schools: an unsustainable situation. Motriz: Revista De Educação Física, 22(4), 310-318. DOI: 10.1590/s1980-6574201600040015. 
Temiz, C.N. ve Sivrikaya, A.H. (2021). Beden eğitimi ve spor dersinde karş̧laşılan sorunların incelenmesi (Yurt içi ve yurt dışı değerlendirmesi). Avrasya Spor Bilimleri ve Ĕ̈itim Dergisi, 3(1), 12-39.

Öncü, E. ve Güven, Ö. (2011). Ana-babaların çocuklarının beden eğitimi dersine katılımına yönelik tutumları. Spor ve Performans Araştırmaları Dergisi, 2(2), 28-37.

Özcan, G. ve Mirzeoğlu, A. (2014). Beden eğitimi öğretim programına ilişkin öğrenci, veli ve beden eğitimi öğretmenlerinin görüşleri. Amasya Üniversitesi Eğitim Fakültesi Dergisi, 3(1), 98-121. DOI: 10.17539/aej.41060.

Özkoparan, O. ve İnan, M. (2018). Beden eğitimi ve spor derslerinde alternatif ölçme-değerlendirme yöntemlerinin kullanılmasına ilişkin öğretmen görüşlerinin incelenmesi. Beden Eğitimi ve Spor Araştırmaları Dergisi, 10(1), 23-38. DOI: 10.30655/besad.2018.0.

Popeska, B., Klincarov, I., Mitevski, O. \& Nikovski, G. (2017). Common obstacles in realization of physical education teaching process in primary education in Republic of Macedonia. 12 $2^{\text {th }}$ FIEP European Congress. Lexembourg.

Richards, K. A. R., Templin, T. J. \& Gaudreault, K. L. (2013). Understanding the realities of school life: recommendations for the preparation of physical education teachers. Quest, 65(4), 442-457. DOI: 10.1080/00336297.2013.804850.

Richardson, K. P. (2011). Physical education teacher education: creating a foundation to increase the status of physical education in schools. Journal Of Physical Education, Recreation \& Dance, 82(7), 45-56. DOI: 10.1080/07303084.2011.10598658.

Rink, J. E. (2013). Measuring teacher effectiveness in physical education. Research Quarterly For Exercise And Sport, 84(4), 407-418. DOI: 10.1080/02701367.2013.844018.

Sáenz-López, P. (2011). Describing problems experienced by spanish novice physical education teachers. The Open Sports Sciences Journal, 4(1), 1-9. DOI: 10.2174/1875399X01104010001.

Sagin, A. E., Gullu, M. Ve Ugras, S. (2020). Beden egitimi zumre ogretmenlerinin 1sbirligi duzeyinin belirlenmesi: bir karma yontem arastirmasi. Mediterranean Journal Of Educational Research, 14(32), 369-388. DOI: 10.29329/mjer.2020.258.19.

Sağın, A. ve Karabulut, Ö. (2020). Beden eğitimi ve spor öğretmenlerinin aldıkları hizmet öncesi eğitime ilişkin algılarının belirlenmesi. Gaziantep Üniversitesi Spor Bilimleri Dergisi, 5(2), 121-133. DOI: 10.31680/gaunjss.728004.

Sanz-Arazuri, E., Ponce-De-León-Elizondo, A., Valdemoros-San-Emeterio, M. \& Baena-Extremera, A. (2017). Parental influence on adolescent adherence to physical sport. Retos, 33, 185-189. DOI: 10.47197/retos.v0i33.54465.

Seçer, T., Çeliköz, N., Kayıl1, G. (2010). Okul öncesi öğretmenliği okul uygulamalarinda yaşanan sorunlar ve çözüm önerileri. Yüzüncü Yll Üniversitesi, Eğitim Fakültesi Dergisi, 7(1), 128-152.

Sezen, M.S. (2019). Beden eğitimi ve spor dersinin uygulanmasında karşılaşılan problemler; okul yöneticileri ve ögretmen görüşleri. Yüksek lisans tezi, Trabzon Üniversitesi, Lisansüstü Eğitim Enstitüsü, Beden Eğitimi ve Spor Ana Bilim Dalı, Trabzon.

Shoval, E., Erlich, I. \& Fejgin, N. (2010). Mapping and interpreting novice physical education teachers' selfperceptions of strengths and difficulties. Physical Education and Sport Pedagogy, 15(1), 85-101. DOI: $10.1080 / 17408980902731350$.

Sönmez, T. ve Sunay, H. (2004). Ankara'daki ortaöğretim kurumlarında uygulanan beden eğitimi ve spor dersinin sorunlarına ilişkin bir inceleme. Milli Eğitim Dergisi, 32(162), 270-277. 
Temiz, C.N. ve Sivrikaya, A.H. (2021). Beden eğitimi ve spor dersinde karş̧laşılan sorunların incelenmesi (Yurt içi ve yurt dışı değerlendirmesi). Avrasya Spor Bilimleri ve Ĕ̈itim Dergisi, 3(1), 12-39.

Şirinkan, A. ve Erciş, S. (2009). İlköğretim okullarındaki beden eğitimi ve spor derslerinde uygulanan öğretim yöntemleri ve ölçme-değerlendirme kriterlerinin araştırılması. Beden Ĕ̆itimi ve Spor Bilimleri Dergisi, 3(3), 184-189.

Taşmektepligil, Y., Yılmaz, Ç., İmamoğlu, O., \& Kılcıgil, E. (2006). İlköğretim okullarinda beden eğitimi ders hedeflerinin gerçekleşme düzeyi. Spormetre Beden Eğitimi ve Spor Bilimleri Dergisi, 4(4), 139-147. DOI: 10.1501/Sporm_0000000070.

Taymaz, H. (2011). Devlet ve özel ilköğretim okullarında görev yapan beden eğitimi ve spor öğretmenlerinin mesleki sorunlarının araştırılması (antalya il örneği). Doktora tezi, Mehmet Akif Ersoy Üniversitesi Sağlık Bilimlieri Enstitüsü, Beden Eğitimi ve Spor Ana Bilim Dalı, Burdur.

Tekkurşun Demir, G., İlhan, E. ve Cicioğlu, H. (2018). Beden eğitimi öğretmen adaylarının gerçeklik şoku beklenti düzeyleri: mesleğe atılmaya hazır mıyız? Türkiye Sosyal Araştırmalar Dergisi, 22(2), 643-658.

Ugras, S. \& Sagin, A.E. (2019). Why do physical education teachers give high grades? Educational Policy Analysis And Strategic Research, 14(4), 256-269. DOI: 10.29329/epasr.

Uğraş, S. (2018). Beden eğitimi öğretmenleri kendilerini hangi konularda yetersiz hissediyor? Çanakkale On sekiz Mart Üniversitesi Spor Bilimleri Dergisi, 1(1), 1-16.

Uğraş, S. ve Akbuğa, T. (2019). Beden eğitimi derslerindeki spor yaralanmaları ve beden eğitimi öğretmenlerinin görüşleri. Uluslararası Dağcllık ve Tırmanış Dergisi, 2(2), 11-26. DOI: 10.36415/dagcilik.657813 .

Uğraş, S. ve Güllü, M. (2019). Beden eğitimi öğretmenliği bölümlerinin yeterliliği ile ilgili öğretmen görüşleri. Anemon Muş Alparslan Üniversitesi Sosyal Bilimler Dergisi, 7(2), 57-65. DOI: 10.18506/anemon.429116.

Uğraş, S., Güllü, M. ve Yücekaya, M.A. (2019). Beden eğitimi ve spor öğretmenliğimde ilk y1lım. Eğitimde Nitel Araştırmalar Dergisi, 7(1), 242-259. DOI: 10.14689/issn.2148-2624.1.7c1s.11m..

Uğraş, S., Güllü, M., Eroğlu, E. ve Özen, G. (2017). Ortaokulda çalışan beden eğitimi öğretmenlerinin okullarda tutulan evrak ve dosyalar hakkındaki düşünceleri. Marmara Üniversitesi Spor Bilimleri Dergisi, 2(2), 8-20. DOI: 10.22396/sbd.2017.27.

Ulucan, H., Türkçapar, Ü. ve Cihan, B. (2012). Beden eğitimi öğretmenlerinin meslekte karşılaştıkları sorunların incelenmesi kırşehir ili uygulaması. Ahi Evran Üniversitesi Kırşehir Eğitim Fakültesi Dergisi, 13(2), 265277.

Ünlü, H. \& Filiz, B. (2019). Work ability of the Turkish physical education teachers. Research Quarterly For Exercise And Sport, 90(4), 666-677. DOI: 10.1080/02701367.2019.1642995.

Ünlü, H. ve Aydos, L. (2010). Beden eğitimi öğretmenlerinin sınıf yönetimi davranışları. Gazi Beden Eğitimi ve Spor Bilimleri Dergisi, 15(1), 45-56.

Veloo, A., \& Md Ali, R. (2016). Physical education teachers challenges in implementing school based assessment. International Review of Management and Marketing, 6(8S), 48-53.

Villalba, A., González-Rivera, M. D. \& Díaz-Pulido, B. (2017). Obstacles perceived by physical education teachers to integrating 1ct. Turkish Online Journal of Educational Technology-TOJET, 16(1), 83-92.

Von Haaren-Mack, B., Schaefer, A., Pels, F. \& Kleinert, J. (2020). Stress in physical education teachers: a systematic review of sources, consequences, and moderators of stress. Research Quarterly For Exercise And Sport, 91(2), 279-297. DOI: 10.1080/02701367.2019.1662878

Whipp, P. R., Tan, G. \& Yeo, P. T. (2007). Experienced physical education teachers reaching their "use-by date" powerless and disrespected. Research Quarterly For Exercise And Sport, 78(5), 487-499. DOI: 10.1080/02701367.2007.10599448 
Temiz, C.N. ve Sivrikaya, A.H. (2021). Beden eğitimi ve spor dersinde karş̧laşılan sorunların incelenmesi (Yurt içi ve yurt dışı değerlendirmesi). Avrasya Spor Bilimleri ve Ĕ̈itim Dergisi, 3(1), 12-39.

Yaşar, G. (2008). Beden eğitimi öğretmenlerinin okulla ilgili sorunları ve stresle başa çıkma tarzlarının bazı değişkenler açısından incelenmesi. Yüksek lisans tezi, Çukurova Üniversitesi, Sağlık Bilimleri Enstitüsü, Beden Eğitimi ve Spor Ana Bilim Dalı, Adana.

Yetim, A. (2000). Sporun Sosyal Görünümü. Gazi Beden Eğitimi ve Spor Bilimleri Dergisi, 5(1), 63-72.

Yıldız, E. ve Kangalgil, M. (2014). Beden eğitimi öğretmenlerinin mesleki yeterlikleri ve kullandıkları öğretim yöntemleri ile ilgili görüşlerinin incelenmesi. Pamukkale Journal Of Sport Sciences, 5(1), 61-76.

Yıldız, M. ve Yıldız, Ö. (2019). Beden Eğitimi Öğretmenlerinin Alternatif Ölçme ve Değerlendirme Yöntemlerini kullanma düzeyleri. Türk Spor Bilimleri Dergisi, 2(1), 60-73.

Yıldız, Y., Yıldız, O. ve Çağlayan, D. (2013). Ortaöğretim beden eğitimi dersi yeni öğretim programının öğretmen görüşleriyle değerlendirilmesi. Bartın University Journal Of Faculty Of Education, 2(1), 253-269.

Yılmaz, A. ve Cihan, H. (2018). Okul yöneticisi, beden eğitimi öğretmeni ve öğrencilerin beden eğitimi dersine ilişkin görüşleri: nitel bir çalışma. Gazi Üniversitesi Spor Bilimleri Dergisi, 23(1), 9-24.

Yılmaz, A., Esentürk, O. ve İlhan, E. (2018). Beden Eğitimi Öğretmenlerinin Mesleki Tükenmişlik Durumları ve Öğretim Sürecinde Bu Duruma Yol Açan Nedenler: Karma Araştırma Yaklaşımı. Kastamonu Eğitim Dergisi, 26(6), 2091-2103. DOI: 10.24106/kefdergi.2448.

Yılmaz, G. ve Gündüz, N. (2008). Ankara merkez ilköğretim okullarında görevli beden eğitimi ve spor öğretmenlerinin ölçme ve değerlendirme tekniklerinin uygulanışına ilişskin görüşleri. Spormetre Beden Eğitimi ve Spor Bilimleri Dergisi, 6(3), 103-111. DOI: 10.1501/Sporm_0000000099.

Yüzüak, E. (2006). Kütahya'da ilköğretim ve liselerde görev yapan beden eğitimi öğretmenlerinin mesleki sorunlarının araştırılması. Yüksek lisans tezi, Dumlupınar Üniversitesi, Sosyal Bilimler Enstitüsü, Beden Eğitimi ve Spor Ana Bilim Dalı, Kütahya.

Zach, S., Dunsky, A., Stein, H., Litvin, O. \& Hellerstein, D. (2020). Novice physical education teachers in israel: Facilitators and barriers to persistence in the profession. Sustainability, 12(9), 3830. DOI: $10.3390 /$ su12093830 .

Zhu, X. (2015). Student perspectives of grading in physical education. European Physical Education Review, 21(4), 409-420. DOI: 10.1177/1356336X15569628. 


\section{EXTENDED ABSTRACT}

\section{Assessing the Problems Encountered in Physical Education and Sport Classes (A Domestic and International Evaluation)}

\section{Introduction}

This research aims to investigate, the problems encountered by physical education teachers in their professional life and the problems associated with teaching of physical education. Physical education is the process of participating in physical movement in accordance with specific objectives. Unlike other fields of education, physical education is based on learning to move through movement (Tamer ve Pulur, 2001, as cited in Karaçam ve Pulur, 2016). Physical education and sports classes should be examined differently than other lessons due to its nature. Specifically, the environment in which these classes are conducted, the equipment used, as well as clothes that students and teachers wear that distinguish them from other lessons (Ünlü ve Aydos, 2010). These features also bring some problems.

\section{Discussion}

The problems experienced by physical education and sports teachers can be grouped under certain themes. These include school management, law-regulation, curriculum, students, parents, undergraduate education, general problems. These obstacles affect both the teaching of the classes and the teacher. These challenges in addition to insufficient undergraduate education and training, unpourable perspectives from the administration, parents and other teachers directed towards the physical education and sport classes and the perception of it being low academic status. Furthermore, problems such as the lack of knowledge and skills of teachers regarding measurement and evaluation and their inability to update their knowledge were also identified. The challenges regarding teaching of the classes include facility shortages, lack of materials and time, crowded classes, disinterested parents, pupils, other teachers, and school administration. The digital age is advancing rapidly, information updated regularly and rapidly. Technological developments are beginning to be intertwined with education; therefore teachers are required to process and implement these developments. During conducted studies, it was determined that in service trainings was both insufficient and inadequate as determined by the teachers. Evidently, it has been reported that similar challenges regarding physical education and sport teachers are experienced not just domestically but internationally also.

\section{Conclusion}

The working conditions, lack of sufficient support, constantly changing environmental factors, workload, negative attitudes towards the course and the teaching profession, insufficient material and facilities affect job satisfaction and increase stress and anxiety levels. The unhealthy working 
conditions pushes teachers to leave their professions. Teachers feel emotionally inadequate and experience intense stress, disappointment, and sadness. This situation causes an increase in the levels of professional and emotional burnout, a feeling of failure and a decrease in their job and life satisfaction. Considering that teachers 'performances are the most important factor in obtaining educational outcomes, it is extremely important to regulate teachers' working conditions and to minimize stressful reasons.

Bu eser Creative Commons Atıf-Gayri Ticari 4.0 Uluslararası Lisansı ile lisanslanmıştır. 